\title{
Policy levers to increase jobs and increase income from work after the Great Recession
}

\author{
David Neumark ${ }^{1,2,3}$
}

\author{
Correspondence: dneumark@uci. \\ edu \\ ${ }^{1}$ University of California, Irvine, \\ Irvine, CA, USA \\ ${ }^{2}$ NBER, Cambridge, MA, USA \\ Full list of author information is \\ available at the end of the article
}

\begin{abstract}
The depth of the Great Recession, the slow recovery of job creation, the downward trend in labor force participation, high long-term unemployment, stagnant or declining wages for low-to-medium skill jobs owing to adverse labor demand shifts, and a greater rebound in low-wage than mid-or higher-wage jobs raised concerns that the normal business cycle dynamics of recovery from the recession will be insufficient to offset the diminished labor market prospects of many workers. These concerns have spurred serious consideration of policies to encourage job creation and higher income from work beyond the more immediate countercyclical policies that were adopted in response to the Great Recession. Among the policies generating continuing or renewed interest are hiring credits, higher (sometimes much higher) minimum wages, and a more substantial earned income tax credit (EITC) for childless individuals. This paper discusses these policy options, what we know about their likely effects and trade-offs, and what the unanswered questions are; the focus is on US evidence.

JEL codes: J2, J3, J6

Keywords: Hiring credits, Wage subsidies, Minimum wage, Earned income tax credit
\end{abstract}

\section{Introduction}

The depth of the Great Recession, the slow recovery of job creation, ${ }^{1}$ the downward trend in labor force participation (Bengali et al., 2013), high long-term unemployment (Kroft et al., 2014), stagnant or declining wages for low-to-medium skill jobs owing to adverse labor demand shifts (Autor, 2011), and a greater rebound in low-wage than mid- or higher-wage jobs (National Employment Law Project, 2012) raised concerns that the normal business cycle dynamics of recovery from the recession will be insufficient to offset the diminished labor market prospects of many workers. These concerns have spurred serious consideration of policies to encourage job creation and higher income from work beyond the more immediate countercyclical policies that were adopted in response to the Great Recession. Among the policies generating continuing or renewed interest are hiring credits, higher (sometimes much higher) minimum wages, and a more substantial earned income tax credit (EITC) for childless individuals.

This paper discusses these policy options, what we know about their likely effects and trade-offs, and what the unanswered questions are; the focus is on US evidence,

(c) 2016 Neumark. Open Access This article is distributed under the terms of the Creative Commons Attribution 4.0 International License (http://creativecommons.org/licenses/by/4.0/), which permits unrestricted use, distribution, and reproduction in any medium, provided you give appropriate credit to the original author(s) and the source, provide a link to the Creative Commons license, and indicate if changes were made. 
although of course the lessons may apply to other countries as well. Its purpose is not to review the vast earlier literature on these policies, but rather, the focus is on recent evidence and-when appropriate-what we can learn from policies adopted during or after the Great Recession. When possible, it references earlier surveys of the larger body of evidence. The focus on the most recent evidence on policies to encourage job creation and higher incomes is informative both because it provides new discussion and analysis of emerging research on recently tried policies and because changes in labor markets and the policy environment can lead to longer-standing labor market policies having different effects now than in past decades. ${ }^{2}$

The research the survey covers is limited to the effects of the policies considered on the targeted groups and does not consider the general equilibrium effects of the taxes or other costs that would or do fund these policies and that could affect other groups or aggregate activity. For example, higher taxes to finance a more generous EITC might reduce labor supply of some (presumably higher-income) groups. Nor does it consider the effects of potential changes in the mix of who works on overall labor productivity. Such an analysis would be much more stylized and model-based, although it could potentially yield useful insights. However, abstracting from aggregate effects, the empirical work undergirding this survey tends to focus on strongly affected groups relative to others (e.g., single mothers, in the case of the EITC), and it seems likely that the kinds of effects the literature detects reflect mainly the direct effects of the policy, rather than the effects of the taxation that finances the policy. And when estimates are based on comparisons across states in how policies impact affected groups, the estimates should reflect general equilibrium effects (although we may still miss effects on groups not directly affected). That is, while the targeted group or partial equilibrium focus no doubt misses some aggregate effects, it seems unlikely to do much to bias estimated effects of policies on the affected groups.

\section{Job creation strategies}

Economic theory predicts that employment can be increased by either subsidizing employers (with a hiring tax credit or a wage subsidy) or employees (through an EITC or another worker subsidy). Both types of policies have been used in the USA, at both the federal and state levels. These sometimes have an explicit distributional goal, but in this section, I focus on job creation.

\subsection{Hiring credits}

Although hiring credits should spur labor demand by lowering labor costs for employers, earlier research generally reaches negative conclusions about their effects, echoed in standard labor economics textbooks (e.g., Borjas, 2010, and Ehrenberg and Smith, 2009). However, most of the earlier evidence is based on credits targeting specific groups-often the disadvantaged.

When hiring credits target the disadvantaged, "stigmatization" of those eligible for the credits can reduce their impact. In particular, eligibility of workers for targeted hiring credits can provide information to employers that they have been unsuccessful in the labor market, which can lead employers to regard eligible workers as risky or as less productive, offsetting the potential impact of the hiring credit (Dickert-Conlin and 
Holtz-Eakin, 2000; Katz, 1998). There is evidence suggesting that narrow targeting of hiring credits stigmatizes the intended beneficiaries, dissipating the effects of the credits. A striking example is an experimental program for welfare recipients in Dayton, Ohio, under the Targeted Jobs Tax Credit (TJTC) (Burtless, 1985). One group received vouchers that they could present to employers for direct cash rebate subsidies, a second group received vouchers that let employers claim hiring credits under one of two existing programs, and a third group was eligible for the same credits, but neither received vouchers to give to employers nor were they told that they were eligible. The third group had the most success in finding employment. Given that assignment to groups was random, so that the only difference was the information given to employers and workers, it is plausible to interpret the worse outcomes for those with vouchers as indicating adverse stigma effects that reduced the effect of the hiring credits.

In the context of battling the aftereffects of severe economic downturns like the Great Recession, however, this perspective may be inappropriate. Compared with hiring credits targeting the disadvantaged, more explicit counter-recessionary hiring credits could be more effective. And although the official end date of the Great Recession is now well behind us, and labor markets are recovering, there are continuing problems of long durations of unemployment, ${ }^{3}$ and research points to specific difficulties of the long-term unemployed in finding new jobs (Kroft et al., 2013). A broader hiring credit focused on the unemployed or those who have been out of the labor force may avoid the problem of stigma, because with high unemployment rates and low participation rates, eligibility for a hiring credit based on current unemployment or nonparticipation may not send employers much of a bad signal. Kroft et al. (2013) provide evidence consistent with this idea. In particular, they find evidence that employers pay attention to labor market conditions in interpreting unemployment as a negative signal. While employers are less likely to call back those unemployed for a longer spell, the stigmatizing effect of a long unemployment spell is weaker in a slacker labor market. Conversely, of course, the effectiveness of such credits in helping the long-term unemployed as the labor market tightens could decline, as stigma concerns associated with long-term unemployment strengthen.

Another factor that may boost the effects of hiring credits in the context of a severe economic downturn is the construction of incentives for new hiring. To create the strongest incentives for employers to create jobs they would not have created absent the credit, and to minimize windfalls to employers, a hiring credit has to identify and reward net (positive) changes in employment that would not have occurred otherwise. Such problems may be particularly problematic for low-skilled or disadvantaged workers, who have high turnover, and may present employers with opportunities to claim credits for repeated hiring of workers that would have occurred anyway because of this turnover. Designing hiring credits that reduce windfalls and incentivize new hiring can require more information from firms, imposing large administrative costs that undermine the job creation goals of these credits by effectively reducing the value of the credit. However, it is likely easier to get the incentives for new hiring right when using hiring credits in a period of anemic job growth. When employment is largely stagnant (or falling), rewarding hiring in a simple manner is less likely to deliver windfalls to firms that would be hiring anyway, hence making it easier to keep administrative costs low. Similarly, a credit targeting the unemployed should be simple to administer, as it is easy to verify unemployment status. 
What do we know about explicit countercyclical hiring credits? At the federal level, countercyclical credits-in contrast to credits targeting the disadvantaged-have been rare. The federal New Jobs Tax Credit (NJTC) was in effect from mid-1977 to the end of 1978, to help spur recovery after the recession earlier in the 1970s (Katz, 1998). The NJTC was "non-categorical" rather than targeting specific groups and used a simple way to reward hiring-offering the credit to firms in which employment rose by more than $2 \%$ and paying up to $50 \%$ of the first $\$ 4200$ in wages per new hire, up to a maximum of $\$ 100,000$ per firm in a year. ${ }^{4}$ More recently, the Hiring Incentives to Restore Employment (HIRE) Act targeted those entering employment from unemployment or out of the labor force, using an exemption from the employer's share of Social Security taxes due for March to December 2010, plus an additional \$1000 credit per worker.

Based on a few studies of the NJTC (see Neumark, 2013, for more discussion), Katz (1998) suggests that the evidence supports the conclusion that a "temporary, noncategorical, incremental employment subsidy" like the NJTC has some potential for creating job growth. However, as is usually the case with federal policies, the effect of the NJTC is hard to distinguish from other time-series changes. Regardless, any such evidence is old. There are no solid evaluations of the HIRE Act.

More recent and potentially more promising evidence can be obtained from statelevel hiring credits. Neumark and Grijalva (2013) document an extensive set of state hiring credits-many enacted during and after the Great Recession. This study assembled a database on state hiring credits, restricting attention to broad, statewide programs that offered credits to employers for creating (or retaining) jobs. Focusing to some extent on hiring credits adopted during or after the Great Recession, this database is used to estimate difference-in-differences models that compare job growth in states that did and did not implement particular types of hiring credits, controlling for other factors to isolate the effects of state hiring credits. ${ }^{5}$

States offer a complex package of incentives ranging from tax incentives based on different criteria (e.g., job creation) to financial assistance, technical support, training, incentives for creation of infrastructure, etc. Neumark and Grijalva restrict attention to programs intended to create (or retain) jobs, based on the following criteria: (1) the program's law or regulations require firms to create or retain jobs or to increase payroll; programs aimed at attracting new companies to the state (e.g., headquarters programs) are also included since by definition they create new jobs and, in most cases, they include an explicit job creation requirement; (2) the program is broad in the sense that it covers a large portion of the state's firms or employees; (3) the program is targeted directly at the employer that is creating jobs; for instance, they do not include programs that foster infrastructure improvement by local governments on behalf of a business that is creating jobs; (4) the program is not geographically targeted. In particular, enterprise zone programs and local hiring programs are excluded; ${ }^{6}$ and (5) the program's costs are not borne by local governments; in particular, property tax abatements and tax increment financing districts are not included.

Also excluded are programs based on training, apprenticeships, or internships, on research and development, or those related to the film industry; and agricultural or financial programs (e.g., programs that provide loans or whose benefits are reductions in the interest rate on previous loans). In contrast, programs that have broad targeting by industry (e.g., manufacturing), by company type (e.g., small businesses), or groups of workers (e.g., the unemployed) are included. 
As Neumark and Grijalva's research documents, over recent decades states have adopted nearly 150 different types of hiring credits. Figure 1 shows the number of new hiring credits implemented each year (from 1969 to 2012). The figure shows that many of these were enacted during and after the Great Recession (9 during the Great Recession and 21 afterwards), which can help provide evidence on whether these credits helped counter-recessionary efforts. There are 45 states that had at least one hiring credit at some point during the whole period. The five states that did not have any program are Alaska, New Hampshire, South Dakota, Washington, and Wyoming. There are also five states that had at most one program: Hawaii, Maine, Minnesota, Montana, and Oregon. The remaining 40 states had two or more hiring credits over the period, and of these, most had two to four credits.

Moreover, a variety of state credits were adopted. The database captures many types of hiring credits, but there are some limitations. First, there is no clear way to distinguish between "small" and "large" programs, since spending is endogenous to firms' decisions, so credits with similar features are treated as homogeneous. Second, for the subperiod capturing the Great Recession and after, there is not that much variation in credits offered. The small number of credits that turn on during the sample period also make it impractical to simultaneously estimate the effects of many (or all) types of hiring credits. Instead, the paper focuses on estimating the effects of "one-way" classifications of hiring credits.

There is an issue of how to measure hiring credit programs. Much of the variation in hiring credits comes from states where a program already existed, sometimes of the same type. For example, in the aggregate, of the 38 programs created from January 2006 to December 2011, 36 were added in states that already had at least one program. Neumark and Grijalva chose to code simply the existence of a credit of a particular type, rather than the number of credits, but the key results (discussed below) were not sensitive to instead using a count of credits by type.

Perhaps the most important control variable is a counterfactual business cycle measure, intended to capture what the impact of the recession in each state would have been absent a state's hiring credit(s). This is constructed by applying national timeseries changes in disaggregated industry employment to the state, based on the state's industry composition in a baseline period of stable aggregate economic growth (as in

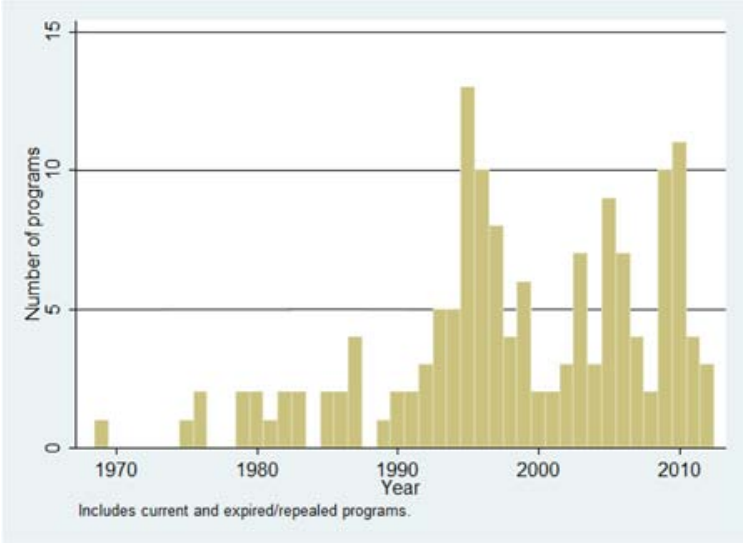

Fig. 1 Number of New Hiring Credits Each Year. Source: Neumark and Grijalva (2013) 
Bartik 1991). ${ }^{7}$ The model also controls for weeks of extended Unemployment Insurance (UI) benefits during and after the Great Recession, which could have slowed job growth, and for minimum wages. In addition, the model controls for other major federal efforts to counteract the Great Recession, with monthly spending, by state, on the federal stimulus (the American Recovery and Reinvestment Act, or ARRA), enacted in $2009 .^{8}$

Results for the Great Recession period are reported in Table 1. Each panel in the table reports estimates looking at different ways of breaking down hiring credits; the second, for example, reports estimates of the effects of credits distinguishing between credits based on new job growth, new payroll growth, new investment, or other criteria. The specifications include contemporaneous dummy variables for the hiring credits, plus 12 monthly lags, and the table reports the contemporaneous coefficients, and then the cumulative effect including lags through 4, 8, and 12 months. Perhaps echoing the often-negative assessment of hiring credits discussed earlier, for many types of hiring credits, the evidence does not point to significant effects on job growth. However, for some types of credits there is evidence of positive effects-often for credits for which we might expect better outcomes.

First, hiring credits vary in terms of tax treatment. Credits may limit the benefit to be equal to the tax liability, or they may allow it to be higher than the tax liability, by letting firms carry credits forward to future years, or making the credit refundable. Refundable hiring credits should have the greatest impact because they are valuable even if the firm has no tax liability-which is more likely during a recession. Second, many programs try to strengthen job creation effects by allowing "recapture" or "clawbacks" of credits if net job creation is lower than required for payment of the credit. ${ }^{9}$ We would expect a recapture mechanism to lead to more effective credits, by either enforcing job creation goals or encouraging only firms that could actually meet them to apply for credits. Third, as discussed above, credits targeting the unemployed during a period such as the Great Recession should not stigmatize eligible workers.

As the table shows (italicized results), the estimated effects of refundable hiring credits are positive, but not statistically significant. For hiring credits with recapture provisions, the estimates are large and statistically significant (at the 5 or $10 \%$ level) through 4, 8, and 12 months. The same is true for hiring credits targeting the unemployed, which have positive and statistically significant effects for all of the cumulative effects reported in the table. ${ }^{10}$

Thus, the evidence from Table 1 suggests that a limited number of specific types of hiring credits enacted during the Great Recession succeeded in boosting employment-specifically, credits that allow for recapture of payments if the required goals were not met and credits targeting the unemployed. ${ }^{11}$ Moreover, the magnitudes sometimes appear quite large. For example, the point estimate for credits targeting the unemployed implies that such a credit boosts employment by $1.16 \%$ after 12 months. We do not have measures of spending on such credits from the states that adopted them, but it is highly unlikely that states spent anything close to $1.16 \%$ of payrolls within their borders on these credits, suggesting the benefits could well outweigh the costs. ${ }^{12}$

Heaton (2012) provides additional evidence on hiring credits adopted during (or just before) the Great Recession, examining the 2007 expansion of the (Work Opportunities Tax Credit, or WOTC) for veterans entitled to compensation for a service-connected 
Table 1 Estimated effects of state hiring credits on employment growth, 2007-2011

\begin{tabular}{|c|c|c|c|c|c|c|c|c|c|}
\hline Credit variable(s) & Contemp. & +4 lags & +8 lags & +12 lags & Credit variable(s) & Contemp. & +4 lags & +8 lags & +12 lags \\
\hline A. ARRA variable & Contemp. & +6 lags & +12 lags & +24 lags & & & & & \\
\hline \multirow[t]{2}{*}{ ARRA } & -0.0017 & 0.0002 & -0.0001 & 0.0017 & & & & & \\
\hline & $(0.0014)$ & $(0.0023)$ & $(0.0029)$ & $(0.0037)$ & & & & & \\
\hline \multirow[t]{2}{*}{ Credit } & 0.0011 & -0.0014 & -0.0067 & -0.0084 & E. Wage requirement & -0.0007 & 0.0023 & 0.0033 & 0.0026 \\
\hline & $(0.0015)$ & $(0.0023)$ & $(0.0040)$ & $(0.0049)$ & & $(0.0010)$ & $(0.0021)$ & $(0.0039)$ & $(0.0040)$ \\
\hline \multirow[t]{2}{*}{ B. Jobs } & 0.0016 & -0.0008 & -0.0035 & -0.0066 & No wage requirement & -0.0008 & -0.0050 & -0.0082 & -0.0135 \\
\hline & $(0.0014)$ & $(0.0025)$ & $(0.0046)$ & $(0.0045)$ & & $(0.0024)$ & $(0.0040)$ & $(0.0057)$ & $(0.0104)$ \\
\hline \multirow[t]{2}{*}{ Payroll } & -0.0009 & 0.0005 & 0.0008 & -0.0004 & F. Recapture & 0.0033 & 0.0057 & 0.0064 & 0.0082 \\
\hline & $(0.0011)$ & $(0.0012)$ & $(0.0030)$ & $(0.0024)$ & & $(0.0023)$ & $(0.0018)$ & $(0.0031)$ & $(0.0042)$ \\
\hline \multirow[t]{2}{*}{ Investment } & 0.0091 & 0.0060 & 0.0053 & 0.0044 & No recapture & 0.0027 & -0.0015 & -0.0040 & -0.0049 \\
\hline & $(0.0012)$ & $(0.0024)$ & $(0.0058)$ & $(0.0043)$ & & $(0.0014)$ & $(0.0020)$ & $(0.0028)$ & $(0.0034)$ \\
\hline \multirow[t]{2}{*}{ Others } & 0.0007 & -0.0034 & -0.0059 & -0.0076 & G.Industry & 0.0001 & -0.0042 & -0.0068 & -0.0094 \\
\hline & $(0.0017)$ & $(0.0029)$ & $(0.0045)$ & $(0.0062)$ & & $(0.0012)$ & $(0.0020)$ & $(0.0029)$ & $(0.0036)$ \\
\hline \multirow[t]{2}{*}{ C. Full-time } & 0.0014 & 0.0004 & -0.0019 & -0.0018 & Manufacturing & -0.0011 & -0.0090 & -0.0091 & -0.0132 \\
\hline & $(0.0015)$ & $(0.0025)$ & $(0.0038)$ & $(0.0058)$ & & $(0.0012)$ & $(0.0028)$ & $(0.0040)$ & $(0.0049)$ \\
\hline \multirow[t]{2}{*}{ Full-time equiv. } & -0.0050 & -0.0076 & -0.0091 & -0.0177 & No targeting & 0.0019 & 0.0003 & -0.0041 & -0.0051 \\
\hline & $(0.0015)$ & $(0.0028)$ & $(0.0054)$ & $(0.0070)$ & & $(0.0012)$ & $(0.0023)$ & $(0.0034)$ & $(0.0040)$ \\
\hline \multirow[t]{2}{*}{ Part-time } & $\ldots$ & $\ldots$ & 0.0006 & 0.0092 & H. Unemployed & 0.0061 & 0.0084 & 0.0082 & 0.0116 \\
\hline & & & $(0.0017)$ & $(0.0034)$ & & $(0.0014)$ & $(0.0021)$ & $(0.0033)$ & $(0.0045)$ \\
\hline \multirow[t]{2}{*}{ Not specified } & 0.0009 & -0.0027 & -0.0049 & -0.0055 & Welfare recipient & $\ldots$ & & $\ldots$ & $\ldots$ \\
\hline & $(0.0010)$ & $(0.0026)$ & $(0.0036)$ & $(0.0050)$ & & & & & \\
\hline \multirow[t]{2}{*}{ D. Equal to tax owed } & -0.0049 & -0.0072 & -0.0115 & -0.0247 & Disabled & -0.0094 & 0.0015 & 0.0034 & 0.0036 \\
\hline & $(0.0012)$ & $(0.0056)$ & $(0.0070)$ & $(0.0137)$ & & $(0.0019)$ & $(0.0033)$ & $(0.0024)$ & $(0.0074)$ \\
\hline
\end{tabular}


Table 1 Estimated effects of state hiring credits on employment growth, 2007-2011 (Continued)

\begin{tabular}{|c|c|c|c|c|c|c|c|c|c|}
\hline \multirow[t]{2}{*}{ Carry-forward } & 0.0012 & -0.0009 & -0.0049 & -0.0051 & No targeting & 0.0012 & -0.0014 & -0.0069 & -0.0084 \\
\hline & $(0.0010)$ & $(0.0046)$ & $(0.0056)$ & $(0.0086)$ & & $(0.0016)$ & $(0.0023)$ & $(0.0041)$ & $(0.0051)$ \\
\hline \multirow[t]{2}{*}{ Refundable } & 0.0012 & 0.0027 & 0.0055 & 0.0017 & I. Temporary & -0.0010 & -0.0032 & -0.0032 & -0.0049 \\
\hline & $(0.0030)$ & $(0.0037)$ & $(0.0042)$ & $(0.0061)$ & & $(0.0020)$ & $(0.0032)$ & $(0.0048)$ & $(0.0080)$ \\
\hline \multirow[t]{2}{*}{ Not specified } & 0.0028 & 0.0003 & -0.0014 & -0.0018 & Permanent & 0.0009 & -0.0030 & -0.0064 & -0.0081 \\
\hline & $(0.0014)$ & $(0.0029)$ & $(0.0040)$ & $(0.0048)$ & & $(0.0009)$ & $(0.0019)$ & $(0.0026)$ & $(0.0035)$ \\
\hline
\end{tabular}

to the contemporne second includes dummy variables for whether there is a credit with each of the four possible bases for benefits, etc. The specification also includes the following: the contemporaneous value and 12 lags of the first difference of the state-specific shock variable (in logs); interactions of the first difference of the shock variable interacted with state dummy variables; the contemporaneous value and 12 lags of the first difference of the log of the minimum wage prevailing in the state; the contemporaneous value and 12 lags of the first difference of the control for extended UI benefits; dummy variable for the political party of the governor

(measured annually); dummy variables for each month in the sample; and interactions between calendar month dummy variables and state dummy variables. We add contemporaneous ARRA-obligated spending, and 24 lass, in log; the 2000-2006 por the $2000-206$ pelod an Source: Neumark and Grijalva (2013), using QCEW data, database on state hiring credits, and other data sources 
disability who were discharged from the service within the past 12 months, or unemployed for at least 6 of the past 12 months before being hired. Heaton uses American Community Survey (ACS) data that allow him to classify eligible workers as well as plausible comparison groups-non-disabled veterans who were discharged in the past 12 months or unemployed for at least 6 of the past 12 months. He also uses the data to add additional levels of differencing that strengthen identification, such as subtracting out differences between disabled and non-disabled non-veterans that would meet the unemployment criterion, or disabled and nondisabled veterans who do not meet the discharge or unemployment criteria. The evidence points roughly to a two percentage point relative increase in employment for disabled veterans who were eligible for the credit. This evidence is more positive than past work on narrowly targeted hiring incentives, which may be related to an absence of stigma (and perhaps even positive attributions) for veterans, as opposed to economically disadvantaged workers. ${ }^{13}$

\subsection{Subsidized wages}

Aggressive wage subsidies were also implemented in response to the Great Recession. The ARRA included a $\$ 5$ billion TANF Emergency Fund, under which states could get substantial reimbursement for subsidizing jobs, which led to the largest expansion of public employment since the Comprehensive Employment and Training Act (CETA) in the 1970s. ${ }^{14}$ States were not limited to creating subsidized jobs programs for families receiving TANF, and many chose a broader target population, using a higher-income threshold, extending the program to the long-term unemployed, etc. (Farrell et al., 2011).

Early studies of these programs focused on implementation-how many subsidized job placements were made. More recent research, however, has tried to provide evidence on the effects of the programs, although very little supports causal inferences. There is an issue of how these programs should be evaluated. It seems most natural to evaluate subsidized jobs programs, like training programs, based on post-participation effects on employment and earnings. However, Pavetti et al. (2011) argue that countercyclical programs intended to keep people working during a downturn should be evaluated based on the number of unemployed people placed in jobs, regardless of how long-term the effects are, as, for example, these jobs might be viewed as a substitute for going on unemployment insurance (UI).

The evidence shows that the program overall resulted in a large number of job placements-approximately 260,000 placements of low-income parents and youth in subsidized jobs during 2009 and 2010 (Warland et al., n.d.), half of these representing summer jobs for youths (Farrell et al., 2011). In addition, evidence from surveys of participating employers (Roder and Elliott, 2013) points to strong support for these programs (not surprisingly viewed only through the lens of the wage subsidy), and Lower-Basch (2011) reports that states found more employers willing to hire the target population than they could accommodate. The large level of placements, if nothing else, differs from criticisms of low take-up for hiring credit programs (e.g., Hamersma, 2003), often attributed to both administrative costs and stigma.

The stigma associated with these wage subsidies may have been lower because of their adoption following a severe recession, when many people were unemployed 
because of negative demand shocks (paralleling the argument for hiring credits targeting the unemployed) and because eligibility for Emergency Fund subsidies was broad compared to earlier credits narrowly targeting the disadvantaged. For example, some states set eligibility based on family income above $200 \%$ of the poverty line (Pavetti et al., 2011). In addition, subsidies of $100 \%$ may have allayed employer concerns about worker quality since they could terminate the worker without having incurred any direct wage costs. Also, in some cases the employer of record was a non-profit intermediary or workforce agency, protecting firms where workers were placed from adverse impacts on their UI tax rating and other legal liability (Lower-Basch, 2011). ${ }^{15}$

Did these wage subsidies lead to job creation? A high number of placements does not imply that the same number of people would not have found jobs absent the wage subsidies, in which case the subsidies would have largely been windfalls to employers. Indeed, Lower-Basch (2011) reports anecdotal evidence that, because program operators under the TANF Emergency Fund programs were working under a very tight time frame and wanted to make maximum use of the funds, they did not prioritize keeping windfalls low but rather focused on minimizing the burden of the program on employers and bringing the program to scale. Moreover, she notes that states did not attempt to set up means of evaluating whether there were net job creation effects. Reflecting this, her discussion of job subsidy programs created under the TANF Emergency Fund mainly reports enrollment numbers. ${ }^{16}$

Another type of evidence that does not address program effects comes from surveys of employers or program administrators. Pavetti et al. (2011) report that administrators of subsidized employment programs surveyed by telephone claimed that the subsidies helped some small businesses expand, although it would be preferable to obtain this (still subjective) information from employers. Roder and Elliott (2013) conducted a telephone survey of employers who took part in job subsidy programs in three states and report that $63 \%$ said they created new positions in order to hire the subsidized workers. Of course, employers may have a vested interested in giving a positive assessment of a program that is to their financial advantage.

Turning to the question of post-program effects, many descriptions of TANF Emergency Fund job subsidy programs note a high degree of placement in unsubsidized jobs after program completion. Lower-Basch (2011) notes that several states and counties reported "retention rates ranging from 10 to 50 percent" (p. 10) and describes a Boston program in which $46 \%$ of graduates obtained unsubsidized employment after the program ended. However, this does not compare experiences of participants and non-participants.

More compelling evidence comes from an earlier evaluation of the State of Washington's Community Jobs Program, which targeted TANF recipients facing significant employment barriers and paid for both wages and support services, using for placement contractors who received incentive payments (Washington State Institute for Public Policy, 2005). This study found higher employment of enrollees in subsidized jobs in a 2-year follow-up, relative to comparable matched TANF clients who did not participate-by $14-24 \%$. There was also a higher incidence of more continuous employment in the follow-up period. Washington did run a job subsidy program under the TANF Emergency Fund ("Job Connection"), but no comparable data with which to estimate the effects of the program seem to be available. 
There is fairly compelling evidence on post-program effects for one Emergency Fund program - the Florida Back to Work Program. Using Florida UI records, Roder and Elliott (2013) study participants and non-participants who were eligible for the program, finding similar employment rates and earnings in the four quarters prior to the program, but higher earnings and employment in the four quarters after the program ended (a difference-in-difference earnings estimate of \$2471). ${ }^{17}$ One finding, which perhaps circles back to the evidence from Neumark and Grijalva (2013) on credits targeting the unemployed, is that earnings gains for the long-term unemployed were also apparent, of about the same magnitude as the overall effect. ${ }^{18}$

Lower-Basch (2011) suggests that these more positive conclusions compared to the research on effects of past hiring credits targeting the disadvantaged may be attributable to the discretionary nature of the TANF Emergency Fund job subsidy programs, in which administrating agencies were "able to select both employers and workers to participate" (p. 2). In contrast, programs like the WOTC were available to any employer who hires from the targeted population and files the required paperwork. Her hypothesis seems especially plausible if agencies received incentives for placements that lasted or led to post-program employment. ${ }^{19}$

Reading about the evidence on wage subsidies, and how employers responded to them, suggests that they operated as "unpaid internships" for the less advantaged. There is a great deal of anecdotal evidence from the popular media about the importance of unpaid internships as a precursor to paid employment for young people in today's labor market. My casual observation, though, is that these unpaid internships are much more feasible for those in higher-income families with parents who can provide support during a period with no income. Perhaps we need to consider making the same kinds of opportunities available to labor market entrants or others who do not have these means of support, although admittedly how to structure such a program is a challenge. Perhaps by making such opportunities available a limited number of times to each person, and restricting subsidies to jobs with training and growth opportunities, participants would use their subsidy strategically to enhance their labor market prospects. Such opportunities may overcome barriers to employment that arise because employers underestimate worker skills or perceive wide variability in skills and are risk averse with regard to this uncertainty.

\subsection{Promising strategies for the long-term unemployed?}

In response to continuing problems of long-term unemployment, the Obama Administration has been securing promises from companies not to discriminate against the long-term unemployed, ${ }^{20}$ and, earlier, the President's proposed American Jobs Act would have prohibited employers from discriminating against unemployed workers when hiring. ${ }^{21}$ The latter proposal would likely have been a challenge to implement and enforce. The former may help, but could certainly be regarded skeptically: What would a company have to gain by not agreeing to sign such a pledge?

The research on state hiring credits and TANF Emergency Fund wage subsidy programs, however, finds some evidence of success of policies targeting the long-term unemployed. The evidence that state hiring credits targeting the unemployed (often the long-term unemployed) are associated with job creation is indirect in that we do not 
know who got jobs. Roder and Elliott's (2013) evidence from the Florida Back to Work Program is more direct, although the program did not specifically target the long-term unemployed but rather those with incomes below $200 \%$ of the poverty line with children who were TANF eligible.

\section{Increasing income from work}

\subsection{The EITC}

The original intent of the EITC in the USA was to boost incomes of low-income families, although it has also been viewed as a means of encouraging work (Eissa and Hoynes, 2011). Figure 2 shows key features of the federal EITC as of 2014. First, it provides supplemental income only to those who are working (with positive earnings). Second, it provides a growing subsidy on the upward sloping part of the schedule (the "phase-in" range), and then at higher income, a higher implicit tax rate as the subsidy is phased out. Third, the subsidy value varies sharply with the number of eligible children. The subsidy and maximum payment are trivial for those without children, but both are much higher for those with children. For example, for a family with two children, in 2014 the maximum credit that could be earned was $\$ 5460$, based on a $40 \%$ subsidy over the first $\$ 13,650$ in earnings. Finally, note that the EITC is based on family income and hence will go to low-income families, and often single-parent families, which have particularly high poverty rates.

The structure of the EITC implies that it creates positive employment incentives on the extensive margin, because for those initially not working there is only a positive substitution effect. On the phase-in range, there are offsetting income and substitution effects, but if the substitution effect dominates, there are also positive labor supply effects on the intensive margin. However, on the "plateau" when the EITC is fixed and on the phaseout range there are negative income effects, and on the phaseout range there is also a higher implicit marginal tax rate, so standard theory would predict labor

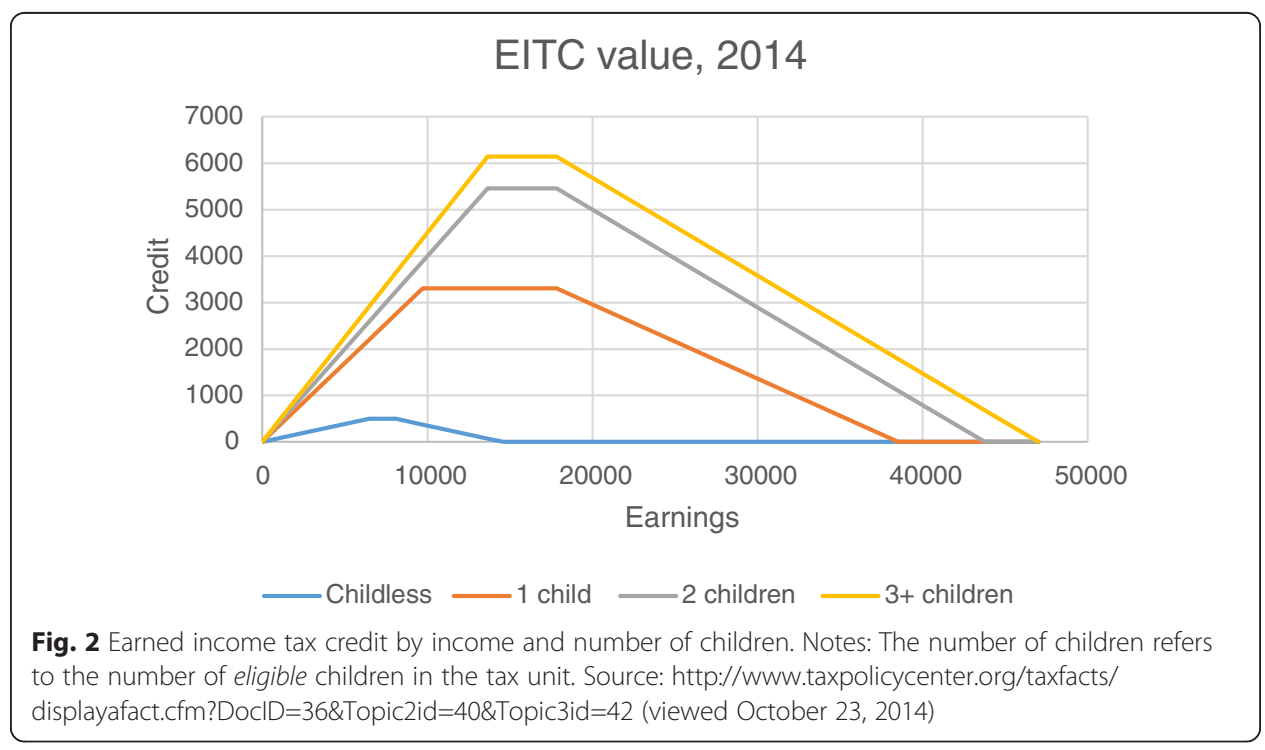


supply disincentives in both regimes, which are strongest in the phaseout range (again, assuming that substitution effects dominate).

Despite these potential labor supply disincentives for some, the EITC has two key strengths. First, it targets low-income families well, with a large proportion of EITC payments going to poor and low-income families (Liebman, 1998). And second, the EITC is a pro-work policy, boosting employment and earnings particularly among single mothers who have low income and might not work absent the EITC, especially if their children are young (Hotz and Scholz, 2003).

One reason the EITC might be more effective than hiring credits at creating jobs is that it presumably does not generate stigma effects, since the employer typically has no idea whether an employee is eligible for or receiving the EITC. ${ }^{22}$ (And as a policy to increase income from work, for the many people already employed who get an EITC payment, stigma is irrelevant.) However, the EITC is likely to be less effective at creating jobs in a period of slack aggregate labor demand, when increased labor supply would not lead to higher employment. ${ }^{23}$ Also, by its structure, the EITC generates large amounts of payments to people who are not induced to enter the labor market and hence generates very large windfalls if viewed as a job creation tool. Reflecting this, back-of-the-envelope calculations suggest that the costs of creating jobs via hiring credits targeting the unemployed probably range from about $\$ 9100$ to $\$ 75,000$ per job, and likely in the lower half of that range if multiplier effects are significant, whereas costs per job created via the EITC are more likely in the range of $\$ 50,000$ to $\$ 117,000$ (Neumark, 2013). Moreover, some research bears out the predicted labor supply reductions among those already working, especially second workers in families. Nonetheless, the evidence points to a positive overall impact of the EITC on women's labor supply (Keane and Moffitt, 1998; Meyer and Rosenbaum, 2001) and on aggregate labor supply, although the aggregate effect is not large (about 20 million hours) relative to total labor input (Dickert et al., 1995). Thus, the EITC should be probably viewed mainly as a tool for increasing income from work, which also has some positive employment incentives.

Most recently, attention has focused on a substantial expansion of the EITC for childless adults (meaning the person has no qualifying children), for whom the EITC paid a maximum of $\$ 496$ (in 2014), less than one-tenth of the maximum credit for families with two or more children. President Obama recently proposed increasing the maximum credit to $\$ 1000$, as well as increasing the income level at which the credit is fully phased out, so that more low-income childless people will benefit from the higher credit. $^{24}$ An expansion of the EITC for childless adults would create additional incentives for employment of eligible individuals, as well as boosting incomes of those employed. The higher-income level at which the credit is fully phased out would have the latter effect but also increase the number of people for whom there would be labor supply disincentives.

The EITC targets poor and low-income families well and has boosted earnings (and employment) among single mothers-who have perhaps been the principal group targeted by the policy (Eissa and Liebman, 1996; Liebman, 1998; Scholz, 1994). Past work focused on the federal EITC, but in more recent work, Neumark and Wascher (2011) estimated the effects of state expansions in the EITC in the 2000s; in the period they studied, from 1996 to 2007, the number of states with a higher EITC increased from 7 states to 19 states and the District of Columbia, boosting the percentage of the 16-64- 
year-old population residing in states that supplement the federal EITC from $14 \%$ to nearly $40 \% .{ }^{25}$ The state variation permits more rigorous identification of the effects of the EITC, by comparing changes across states, over time, for families with the same number of children, in states with differential changes in the EITC.

This work estimates the effects of the EITC on the probability that a family's earnings are below the poverty line, and below one-half the poverty line ("extreme poverty"). Given that the EITC also results in transfers to eligible families, the benefits are likely greater than those found for earnings, although some transfer income may decline in response to higher earnings. Regardless, focusing on earnings captures the incentive effects of the EITC, and in that sense, this analysis provides a rather strict test of the power of the EITC to increase income from work, by excluding the work-contingent transfers of the EITC (which are also excluded from official US poverty calculations).

Key results are reported in Table 2 . The generosity of the EITC is measured by the percentage state supplement to the federal EITC. Because the EITC is much more generous for families with children, the coefficient on the interaction between the EITC and an indicator for the presence of dependent children age 18 or under in the home (which is what is measured in the Current Population Survey (CPS)) is viewed as capturing the effect of the EITC. The main effect could be interpreted as the effect of the EITC on those without children, but this parameter more likely reflects the effects of shocks specific to state and year cells that are correlated with the EITC. The EITC $\times$ kids interaction is then a difference-in-difference-in-differences estimator, identifying the effect of the EITC from the differential effect for those with and without children, which cannot be done using federal EITC variation only.

The evidence shows that state-level EITCs are associated with reductions in the proportion of affected families with very low earnings. The negative estimates are larger when the sample is restricted to families headed by single females or families headed by

Table 2 Estimated effects of EITC on family earnings relative to poverty, family heads, or individuals, aged 21-44, 1997-2006

\begin{tabular}{|c|c|c|c|c|c|}
\hline & & $(1)$ & $(2)$ & (3) & (4) \\
\hline & & $\begin{array}{l}\text { Family head } \\
\text { or individual }\end{array}$ & $\begin{array}{l}\text { Single female family } \\
\text { head or individual }\end{array}$ & $\begin{array}{l}\text { Single female family } \\
\text { head or individual, } \\
\text { high-school degree } \\
\text { at most }\end{array}$ & $\begin{array}{l}\text { Single female family } \\
\text { head or individual, } \\
\text { black or Hispanic }\end{array}$ \\
\hline \multicolumn{6}{|c|}{$P$ (earnings < poverty) } \\
\hline EITC $\times$ kids & & $-.04(.07)$ & $-.16(.17)$ & $-.24(.18)$ & $.06(.28)$ \\
\hline EITC & & $-.00(.05)$ & $-.06(.08)$ & $-.02(.10)$ & $-.12(.18)$ \\
\hline \multicolumn{6}{|c|}{$P$ (earnings $<.5$ poverty) } \\
\hline EITC $\times$ kids & & $-.09(.06)$ & $-.34(.18)$ & $-.42(.23)$ & $-.14(.25)$ \\
\hline EITC & & $.02(.04)$ & $.00(.06)$ & $.05(.09)$ & $-.14(.14)$ \\
\hline$N$ & & 362,811 & 98,327 & 65,839 & 34,267 \\
\hline
\end{tabular}

Notes: All estimates are weighted, and standard errors are clustered on states. Linear probability estimates are reported. The regression also includes controls for the number of children, dummy variables for education (high-school dropout, high-school degree, some college, bachelor's degree or higher), dummy variables for number of children as well as the number of children under age six (all observed values), dummy variables for marital status (never married; married spouse present; married spouse absent; and divorced, widowed, or separated), dummy variables for black or Hispanic, age and its square, the state unemployment rate, and state and year fixed effects. In addition, the model includes a full set of interactions between kids and both the year dummy variables and the state dummy variables. The estimated coefficients of the EITC-kids interactions are robust to including state-specific linear trends, or state-year interactions; in the latter specifications, the main EITC effect drops out. The sample is restricted to heads of families, primary individuals, or unrelated individuals.

Source: Neumark and Wascher (2011), using CPS Annual Demographic Files 
less-educated single females, but not when we focus on families headed by single minority women. The estimates are not statistically significant for the poverty line regressions, but two of them are for the probability that family earnings are below one-half of the poverty line. Overall, this evidence bolsters earlier conclusions that the federal EITC helps low-income families, in this case by boosting earnings. ${ }^{26,}{ }^{27}$ And of course it also shows that state-level EITCs are effective.

The core argument for expanding the EITC for individuals without eligible children is to offset the long-run decline in real wages for low-skilled men. Multiple benefits of a more generous EITC-acting via both increased earnings and higher employment-are conjectured. Higher returns to work can have longer-run impacts on earnings through the accumulation of labor market experience. Berlin (2007) also suggests that higher income for low-skill men may make them more attractive marriage partners, helping reverse declines in marriage and increases in out-of-wedlock childbearing, and reduce crime by increasing the relative returns to market work versus illicit sources of income. Gitterman et al. (2008) suggest that an expanded EITC for individuals without qualifying children could partly go to child support owed by non-custodial parents with responsibility for children; Carrasso et al. (2008) point out that many non-custodial fathers face high marginal tax rates because of child support payments, which a subsidy from an expanded EITC could help offset.

What does the evidence say about the potential benefits of expanding the EITC for those without children? There is evidence for men from New Hope, a program that offered work-contingent supplements to single men and generally produced positive effects on employment, earnings, and family income, even up to 5 years after the program, although many of the estimated effects are not significant (Duncan et al.: The persistence of New Hope's labor market impacts: How long? How real?, Unpublished) ${ }^{28}$ I am not aware of evidence on crime, but recent work by Autor et al. (The labor market and the marriage market: how adverse employment shocks affect marriage, fertility, and children's living circumstances, Unpublished) suggests that exogenous labor demand shocks that reduce employment opportunities for less-skilled males lead to lower marriage rates and more teen births as well as more children living in single-parent or poor households. ${ }^{29}$

However, it is important to keep in mind that if the EITC strengthens employment incentives for one group; it may increase competition with other groups and hence can lower their earnings. For example, Neumark and Wascher (2011) show that the current EITC, which boosts employment of single mothers, has some negative spillover effects on other less-skilled individuals who are "ineligible" for the EITC but who compete for jobs with the new labor force entrants.

Using similar specifications to those described above, Neumark and Wascher estimate the effects of the EITC on individuals who seem likely to be substitutes for women benefiting from the EITC-less-educated childless men and women between the ages of 21 and 34, less-skilled subgroups among these, such as less-skilled minorities, and finally less-skilled minority single men. As shown in Table 3, for lesseducated, childless individuals, the estimated EITC effects on wages, employment, and earnings are negative, although not statistically significant. However, for less-educated blacks and Hispanics the estimated effects of the EITC on employment and earnings are negative and statistically significant, and the point estimates are larger. The results 
Table 3 Estimated effects of EITC on low-skilled, childless individuals, aged 21-34, 1997-2006

\begin{tabular}{llll}
\hline Low-skilled treatment group & $\begin{array}{l}\text { (1) } \\
\text { Less-educated } \\
\text { individuals }\end{array}$ & $\begin{array}{l}\text { Less-educated, } \\
\text { black or Hispanic }\end{array}$ & $\begin{array}{l}(3) \\
\text { Less-educated single, } \\
\text { black or Hispanic men }\end{array}$ \\
\hline $\begin{array}{l}\text { Log wages } \\
\text { EITC } \times \text { low-skill }\end{array}$ & $-.10(.09)$ & $-.11(.08)$ & $-.13(.09)$ \\
EITC & $.08(.07)$ & $.06(.10)$ & $.08(.11)$ \\
$N$ & 131,181 & 79,362 & 67,399 \\
Employment & & & $-.16(.05)$ \\
EITC $\times$ low-skill & $-.05(.05)$ & $-.12(.05)$ & $.01(.03)$ \\
EITC & $.02(.04)$ & $.03(.03)$ & 74,913 \\
$N$ & 150,486 & 90,408 & \\
Log earnings & & & $-1.75(.56)$ \\
EITC $\times$ low-skill & $-.58(.49)$ & $-1.32(.44)$ & $.35(.29)$ \\
EITC & $.35(.38)$ & $.40(.37)$ & 74,913 \\
$N$ & 150,486 & 90,408 & \\
\hline
\end{tabular}

Notes: Most notes from Table 2 apply, except those pertaining to variables measuring the number of children. The log wage regressions condition on positive earnings and hours of work in the previous year. "Less-educated" means that the individual has a high-school degree at most. The low-skilled treatment group is defined in the column heading. The control group does not change across columns and always includes all those with at least some college (regardless of race, ethnicity, or marital status). The estimated coefficients of the EITC-low-skill interactions are robust to including state-specific linear trends, or state-year interactions

Source: Neumark and Wascher (2011), using CPS Annual Demographic Files

for less-educated single minority men are stronger still, with the estimates pointing to negative effects of the EITC on wages, employment, and earnings. Other evidence reported in the study indicates similar negative effects of the current EITC based on proxies for the share of women in each state who are eligible for the EITC.

If the EITC adversely affects those with whom currently eligible women compete, the implication is likely that if we expand the EITC for those without children, there is likely to be some shifting of the benefits of the EITC program as a whole away from families, as the eligible participants with children face increased labor supply from unrelated individuals. This may be an acceptable trade-off, in light of arguments for increasing work incentives for those who currently get very little from the EITC. But it is a trade-off that needs to be kept in mind.

There are a number of questions we need to know more about to assess these trade-offs. First, would an expanded EITC increase resource flows to children of non-custodial parents? Second, would a substantial employment impact from an expanded EITC enhance earnings of men in the longer run from higher labor market experience ${ }^{30}$ Third, do the kinds of effects that Autor et al. (The labor market and the marriage market: how adverse employment shocks affect marriage, fertility, and children's living circumstances, Unpublished) find carry over to the EITC? Fourth, would an expanded EITC have greater effects on the extensive margin-hence increasing work-or on the intensive margin-hence reducing labor supply of men but at the same time increasing total income (earnings plus EITC) and raising low-skilled wages? ${ }^{31}$ Despite these unknowns, given the severity of the labor market problems facing low-skilled men, it is probably worthwhile to implement an expanded EITC for those without children on a modest scale, with an eye to addressing these questions-including the trade-offs with other EITC recipients. 
We might also consider expanding the generosity of the EITC more generally. If we are going to use public policy to try to counter rising income inequality, the EITC may be the best tool that we have. In addition to the strengths of the EITC discussed above, it has two other important advantages. First, it is consonant with the pro-work orientation that, in the US context, is most likely to attract bipartisan political support. Second, the EITC is well suited to the policy objective that "no one who works full-time should have to raise their family in poverty", ${ }^{32}$ because the EITC targets poor and low-income families, and its parameters can be chosen to achieve these goals. Finally, as Mankiw has argued, the EITC redistributes income by taxing those who earn the most (and redistributing to those who earn the least subject to working), which seems a sensible form of redistribution. ${ }^{33}$

Some critics deride the EITC as "corporate welfare", with taxpayers subsidizing the low wages paid by employers, who absent the policy would pay higher wages. ${ }^{34}$ However, lower market wages are a necessary consequence of the pro-work incentives of the EITC. Moreover, workers eligible for the EITC end up earning more per hour once the credit is factored in-which is the reason labor supply increases. But wages for those not eligible for the EITC will be lower, as we saw above, and Rothstein (2011) presents simulations suggesting that employers capture substantial gains via lower wages. ${ }^{35}$ Thus, what one makes of this criticism of the EITC hinges on the distributional goals of the policy.

\subsection{Mandating higher wages}

Policymakers and the public have recently strongly embraced higher minimum wages to try to increase income from work. Since the last federal minimum wage increase in 2009, 23 states have raised their minimum wage (Fig. 3). City-level minimum wages that are much higher than state minimum wages are also being enacted at a high rate. For

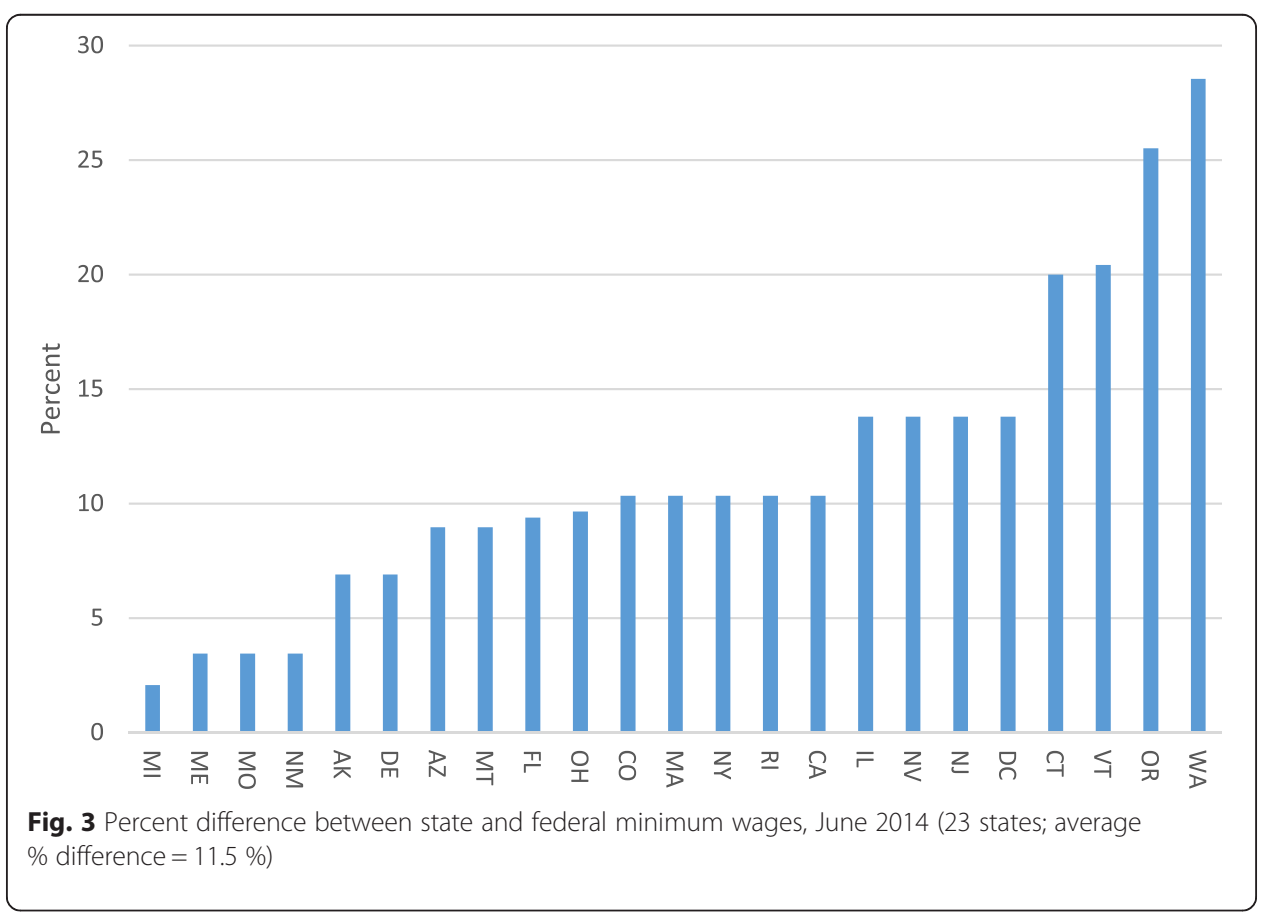


example, California's minimum wage is $\$ 10$ per hour. But San Francisco recently increased its minimum wage to $\$ 12.25$, and it will increase to $\$ 15$ by 2018 and be indexed to inflation thereafter. Los Angeles will raise the minimum wage to \$10.50 in 2016 and then to $\$ 15$ by 2020 . And Oakland recently raised its minimum wage to $\$ 12.25$ per hour.

The main argument for a minimum wage is that it helps poor and low-income families achieve a sufficient level of income. Such benefits would come, of course, from higher wages for affected workers. The potential downside of a minimum wage, however, is that it may discourage employers from using low-wage, low-skill workers. If minimum wages destroy jobs for low-skill workers, then minimum wages create both winners and losers. Whether or not a minimum wage reduces poverty or helps lowincome families then depends on what minimum wages do to workers' earnings, taking account of both wage and employment (and potentially hours) effects, and where in the distribution of family incomes the winners and losers in terms of workers' earnings are located. But clearly the effect on jobs is critical for the relative magnitudes of the potential trade-offs between winners and losers.

\subsubsection{Employment effects}

Because the minimum wage literature covers scores of studies over many decades, I cover the earlier literature with brief reference to prior summaries of the evidence, before turning to a spate of recent evidence. Most of the early studies of the employment effects of minimum wages used aggregate time series data for the USA, estimating the effects of changes in the national minimum wage on employment rates of 16-19-year-olds ("teens") or 16-24-year-olds ("young adults"). A comprehensive summary of these early studies found elasticities for teen employment clustered between -0.1 and -0.3 (Brown et al., 1982).

Research beginning in the early 1990s exploited an increasing number of states raising their minimum wages above the federal minimum. This variation made it possible to compare changes in youth employment between states that did and did not raise their minimum wage-the latter serving as "controls"-helping to untangle the effects of minimum wages from other aggregate influences on youth employment. The range of estimated employment effects widened, in part because the state variation in minimum wages presented researchers with a greater variety of ways to estimate employment effects.

Neumark and Wascher (2007) surveyed evidence from more than 100 studies from this new generation of research-most for the USA. The survey did not simply tabulate the estimates, but rather provided an attempt to identify the most reliable studies and to summarize the evidence from them. It concluded that the strong preponderance of the evidence points to disemployment effects. Nearly two thirds of all the studies surveyed gave consistent evidence of negative (although not always statistically significant) effects of minimum wages, while only eight gave a relatively consistent indication of positive employment effects. In addition, among the 33 that were viewed as providing the most credible evidence, 28 , or $85 \%$, pointed to negative employment effects. Moreover, disemployment effects of minimum wages were strongest when researchers focused on the least-skilled workers most affected by minimum wages. One might disagree with the authors' assessment of the most reliable studies, but it is, nonetheless, most accurate to characterize the overall literature this survey covers as providing a 
rather clear signal of negative employment effects for the least-skilled workers most likely to be affected by minimum wages.

Some recent research, however, strongly contests the conclusion that minimum wages cause job loss. One challenge comes from meta-analyses-or appeals to averages of estimates across studies (Doucouliagos and Stanley, 2009, hereafter DS; Belman and Wolfson, 2014). As a prime example, Schmitt (2013) emphasizes evidence from DS, shown in Fig. 4. Schmitt's key argument is that the estimates are "heavily clustered at or near zero employment effects" (p. 4). That might be a reasonable first impression from the figure. But as DS report, the mean across the studies summarized in the graph is around -0.19 , although it is hard to discern this because the vertical line in the figure is drawn at zero, and-despite most credible studies of minimum wages yielding elasticities in the range of, say, -0.5 to $0.1-$ in the figure the elasticities range from near to -20 to 5 (that is, 40 to 50 times larger than the endpoints of this range), making it very hard to see the graph's central tendency. ${ }^{36}$

In fact, DS focus more on the issue of publication bias in the published literature on minimum wages. However, it is very hard to distinguish between publication bias and other sources of patterns in the published evidence consistent with publication bias. For example, meta-analyses like Doucouliagos and Stanley argue that if published negative estimates of minimum wage effects have larger standard errors, this is evidence of publication bias. However, the same phenomenon can arise if studies using better research designs lead to "truer" estimates, which happen to be negative, and which have larger standard errors because they demand more of the data.

Moreover, averaging across estimates from studies of minimum wage effects, as meta-analyses do, is problematic. First, the population studied varies, and this and other factors can influence how binding the minimum wage is, generating variation in estimated effects that there is no reason to simply average. For example, Neumark and Wascher (2007) document how studies that more sharply focus on workers most likely to be affected by minimum wage increases reveal clearer evidence of disemployment effects. Among other factors potentially influencing the magnitude of the

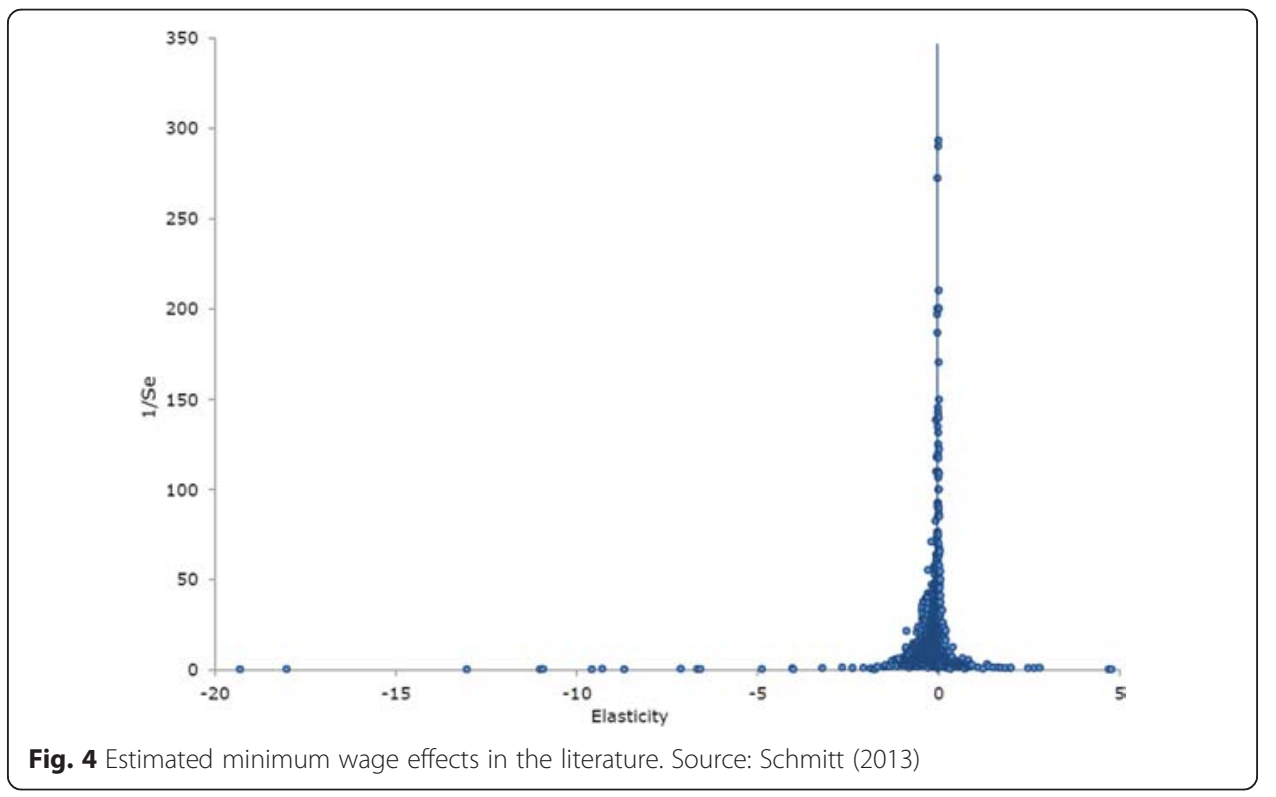


effect is of course how binding the minimum wage is, which may not be captured well in a linear or log-linear model (Neumark and Wascher, 2002; Thompson, 2009), and which can influence whether minor non-employment adjustments such as converting benefits to wages can accommodate the increase, or whether employment reductions are more likely.

Second, meta-analyses often assign more weight to estimates that are more statistically precise (e.g., Belman and Wolfson, 2014), even though the most rigorous empirical methods are likely to be less precise-exactly what we see in many of the new papers discussed below-because of more rigorous research designs. Yet it is precisely the studies using the most rigorous methods-if valid - that that should receive the most (if not all the) weight. Moreover, if we think the studies using less-rigorous methods (e.g., failing to instrument for an endogenous policy, or using a less-saturated model that does not account for some sources of heterogeneity bias) lead to biased estimates, we should not incorporate these studies at all in "aggregating" across the research literature-even less should we up-weight the biased estimates because they have smaller standard errors. For example, as discussed below, Dube (2011) argues that much of the state panel data research was invalid, and generating causal estimates of the effects of minimum wages requires comparing geographically close areas. If he is right, then there is no reason to include the state panel data studies in averages of estimated minimum wage effects, and more generally, geographically-proximate methods should not be down-weighted because they produce less precise estimates, which they do (Neumark et al., 2014a). In short, in economic research there really is no substitute for critical evaluation of alternative studies to select those we view as most rigorous. The meta-analysis "paradigm" for combining estimates from many similar studies-say, randomized trials of a drug (Hunt, 1997) - carries over poorly to the minimum wage literature (and likely many other literatures in economics), although it can still be useful in identifying features of studies that lead to differences in estimates (as in, for example, work on the returns to schooling by Ashenfelter et al., 1999).

A second challenge to the conclusion that minimum wages cause job loss comes from the studies of Allegretto et al. (2011) and Dube et al. (2010). These studies speculate that state minimum wages tend to increase in states and years when labor market conditions for less-skilled workers were in decline relative to other states and relative to labor market conditions for other workers in the same state, generating a spurious negative relationship between minimum wages and low-skilled employment. These studies also assert that restricting comparisons to what happens in nearby states when minimum wages increase in one state but not another solves this problem because it removes spatial heterogeneity in these negative shocks, and the studies find that estimated employment effects from this approach are near zero. ${ }^{37}$

However, Neumark et al. (2014a, 2014b) present evidence that nearby state (or crossborder) counties do not provide better controls for estimating the employment effects of minimum wages, and that using controls picked more by the data than by assumption supports the conclusion that minimum wages reduce employment of less-skilled workers, for teens, in particular, for whom they estimate employment elasticities near -0.15 . They also suggest that using geographically-proximate comparisons can lead to bias against finding disemployment effects of minimum wages, because nearby states 
may differ more with respect to youth labor market conditions prior to minimum wage changes, than with respect to other more exogenous factors that vary across more disparate states, and minimum wages are more likely to be raised when youth labor markets are stronger. ${ }^{38}$ Most recently, Allegretto et al. (2015) offer some rebuttals to these criticisms.

Additional analyses that wrestle with this issue of the choice of controls reach different conclusions, although nearly all point to disemployment effects. Totty (2014) uses a factor model that is a bit more flexible than the standard panel data approach but still not as flexible as letting the data freely dictate what the control states are. He concludes that the estimated employment effects for restaurant workers are close to zero, while for teens estimates are in the 0 to -0.13 range, but mostly close to zero and statistically insignificant. In contrast, Powell (Synthetic control estimation beyond case studies: does the minimum wage decrease teen employment?, Unpublished) improves upon Neumark et al. (2014b) to develop a synthetic control approach that can be applied to the minimum wage case with multiple treatments and continuous variation and which simultaneously estimates the weights on different states as controls as well as the minimum wage effect. This appears to be the most satisfactory and flexible approach, to date, of letting the data choose control states, and generates a statistically significant estimated elasticity for teens of -0.10 .

Baskaya and Rubinstein (Using federal minimum wage effects to identify the impact of minimum wages on employment and earnings across U.S. states, Unpublished) also confront the issue of an endogenous relationship between teen employment and minimum wages, but using an instrumental variables (IV) approach. They instrument for state minimum wages with the federal minimum wage interacted with the propensity for states to let the federal minimum wage bind, purging the estimated minimum wage effect of the variation that could come from state policymakers responding to statelevel economic conditions. Consistent with minimum wages being increased when youth labor market conditions are strong-in contrast to the conjecture in Allegretto et al. and Dube et al.--their IV estimates point to stronger disemployment effects than many past studies, with an elasticity of employment for teenagers that is often closer to -0.5 .

Clemens and Wither (2014) confront the same issue in a different way. They focus on the 2007-2009 federal increases, comparing changes in employment for those whose wages were swept up by the federal increases (because of lower state minimum wages) to changes for workers who earned wages that were low but above the levels to which the federal minimum wage increased. This approach helps circumvent the issue of spurious correlations between employment changes and minimum wage changes across states, by using within-state variation in effects of minimum wage changes, although there is a challenge in estimating the effects of minimum wages (or other policies) during the tumultuous Great Recession period. They find an employment elasticity for directly affected workers of about $-2 / 3$, which is likely larger (negative) compared to other studies because it is calculated for a more directly targeted group of workers (discussed more below). Nonetheless, this elasticity may be more relevant to policy, because it measures employment effects among those most directly affecte$\mathrm{d}$-and hence most directly helped, potentially_by a minimum wage increase. When they apply these methods to teenagers or restaurant workers, the estimate is smaller in 
absolute value, reflecting the fact that not all teenagers or restaurant workers are affected by the minimum wage.

Thompson (2009) uses an alternative approach that also sidesteps the problem of the choice of control states, comparing areas (rather than workers) within states, which permits him (like Clemens and Wither) to control for shocks to state economies in an unrestricted way. Using the variation in state minimum wages generated by the federal increases in 1996 and 1997, he shows that the state-level analyses that characterize nearly all US minimum wage studies mask adverse effects in counties where wages are lower and workers are lower skilled, and hence minimum wages are more binding. For example, for counties in the bottom third of the teen earnings distribution within a state, a $10 \%$ federal increase in a year reduced the teen employment share around $3 \%$, while at the state level, the estimated effects are small and not statistically significant. ${ }^{39}$

Thompson's results do not change the answer to the question of how a higher state minimum wage affects teen or low-skill employment at the state level. However, they do imply that minimum wages have adverse effects exactly where they are intended to do the most good-where skills and wages are low. Moreover, Thompson's results raise doubts about appealing to small estimates of minimum wage effects on employment from state-level studies to argue that city-level minimum wages will not cause job loss-especially for cities or sections of cities where minimum wages would affect many workers.

Finally, Liu et al. (Impact of the minimum wage on youth labor markets, forthcoming) address the spatial heterogeneity issue by controlling for common shocks to economically-integrated areas. They estimate a standard fixed effects model at the county level but including interactions between dummy variables for each quarter and Bureau of Economic Analysis (BEA) "Economic Areas." Because of how they are defined, these areas should experience common economic shocks, and since some of them cross state lines, minimum wage effects can be identified from state variation within these areas (see, e.g., Johnson and Kort, 2004). The idea, in the context of the recent literature, is that the BEA designations explicitly identify cross-border areas that are good controls for each other. Liu et al. find strong evidence of disemployment effects for the youngest group covered in their data (14-18-year-olds), which are diminished only slightly-to an elasticity of -0.17-when the Economic Area-by-quarter interactions are included.

Finally, a different approach taken in recent research focuses on the dynamic effects of minimum wages-how they might affect job growth and hence employment over the longer term, even if the immediate effects are small. One way to motivate a more slowly evolving, longer-term effect via job growth is that when new firms are created, they can choose their technology to minimize costs given the prices of current inputs, including low-skilled labor. But the technology is then relatively fixed, with limited possibility for adjustment if, say, the minimum wage increases. Over time, though, firms created after a minimum wage increase will use technologies that economize more on low-skilled labor, so that employment responds little right away to a minimum wage increase, but over time more low-skilled jobs are eliminated. Meer and West (Effects of the minimum wage on employment dynamics, forthcoming) find evidence consistent with this story, finding a longer-run elasticity for overall employment of about -0.07 . This paper is unique, I believe, in reporting negative effects for overall employment, and such a conclusion merits further scrutiny. However, the authors do present some 
evidence that these negative results come from industries with larger shares of lowskilled workers, although there are some exceptions.

This recent evidence is summarized in Table 4. The table emphasizes a couple of key points. First, many studies-including many recent studies-find that higher minimum wages reduce employment of teens and low-skilled workers more generally. The exceptions in recent work that find no evidence of employment effects generally come from one specific way of estimating the employment effects of minimum wages-focusing on geographically-proximate controls-that has been subject to some criticism and may well obscure the disemployment effects of minimum wages. Moreover, a variety of other methods in the most recent research find disemployment effects-including many that take different approaches to the potential problem of spatial heterogeneity that can bias state-level estimates. Thus, although the evidence on the employment effects of minimum wages remains contested, this overview shows that many types of studies continue to show disemployment effects of minimum wages, and helps clarify what types of studies do and do not lead to this conclusion. In addition, it demonstrates that blanket statements such as "There's just no evidence that raising the minimum wage costs jobs, at least when the starting point is as low as it is in modern America" (Krugman, 2015) are untrue and can only be supported by a sharply selective reading of the evidence.

\subsubsection{Income effects}

Despite employment costs, a higher minimum wage could help poor and low-income families, on net, if it delivers more in the way of wage gains than job losses to such families. Let us first consider the potential impact of minimum wages on workers' earnings and then turn to family incomes.

It is often asserted that because estimated employment elasticities in the range -0.1 to -0.2 are well below 1 in absolute value, the earnings of affected workers, on the whole, will rise substantially when the minimum wage is raised (for example, Freeman, 1996). However, this type of estimated elasticity is not the correct one to use in asking whether workers' earnings rise when the minimum wage goes up, for two reasons. First, the estimated elasticity from the usual minimum wage study typically understates the elasticity of demand for affected workers because not all workers included in the study are affected. To see this in the context of a study of teenagers, for example, we can write the minimum wage elasticity for all teenagers as a weighted average of the elasticity for workers directly affected by a change in the minimum wage and the elasticity for workers currently earning above the minimum wage, or

$$
e=e^{\mathrm{A}} \cdot p^{\mathrm{A}}+e^{\mathrm{NA}} \cdot\left(1-p^{\mathrm{A}}\right)
$$

where $e$ is the estimated elasticity for teenagers as a whole, $e^{\mathrm{A}}$ and $e^{\mathrm{NA}}$ are the minimum wage elasticities for affected and unaffected workers, and $p^{\mathrm{A}}$ is the proportion directly affected by the change in the minimum wage. If we assume that the elasticity for unaffected workers is zero, then the minimum wage elasticity for affected workers $\left(e^{\mathrm{A}}\right)$ can be written $e^{\mathrm{A}}=e / p^{\mathrm{A}}$. It follows that the minimum wage elasticity for affected teenage workers is greater than the elasticity estimated for teenagers as a whole, which is also true if $e^{\mathrm{NA}}$ is nonzero but smaller than $\mathrm{e}^{\mathrm{A}}$. 
Table 4 Key early, recent, and summary estimates of minimum wage effects on unskilled employment

\section{Authors \\ Early estimates/summary}

Brown et al. (1982)

Recent summaries/meta-analyses

Neumark and Wascher (2007)

Doucouliagos and Stanley (2009)

Belman and Wolfson (2014)

Recent estimates

Geographically-proximate changes

Dube et al. (2010)

Near zero for teens and restaurant workers

Allegretto, Dube, and Reich (2011) Near zero for teens

Gittings and Schmutte: Getting

handcuffs on an octopus:

minimum wages, employment,

and turnover, Unpublished

Addison et al. (2013)

Other approaches

Neumark et al. (2014a, 2014b)

Totty (2014)

Powell: Synthetic control

estimation beyond case studies:

does the minimum wage

decrease teen employment?

Unpublished

Employment elasticity and groups studied (0.2 to 0.46$)$
Data/approach

-0.1 to -0.3 , mostly for teenagers, -0.1 to -0.2 for $16-24$-year-olds

Aggregate time series

Many estimates in the range of -0.1 to -0.2 for teens and other low-skilled groups; sometimes larger negative when focusing more specifically on least-skilled groups

Average across studies of -0.19 for teens and low-skilled; 0.04 using their correction for publication bias

Narrative survey of many papers

Meta-analysis, average across many studies Range of estimates from averaging across studies for teens and low-skilled, -0.03 to -0.10 ; when weighted Meta-analysis, average across many studies inversely by precision, -0.03 to -0.10 ; with corrections for publication bias, -0.02 to -0.06

Near zero for teens; larger negative elasticities in markets with short non-employment durations $(-0.1$ to -0.98$)$ and smaller positive elasticities in markets with long non-employment durations

Varying sign, more negative, generally insignificant for restaurant workers and teens; stronger negative at the height of Great Recession $(-0.34)$

$-0.14 /-0.15$ for teens, $-0.05 /-0.06$ for restaurant workers

Most near zero, some near -0.04 for restaurant workers; 0 to -0.15 for teens
Paired counties on opposite sides of state borders States compared only to those in same Census division States compared only to those in same Census division

Similar methods to Dube et al. (2010) and Allegretto et al. (2011), restricted to the 2005-2010 period

States compared to data-driven choice of controls (synthetic control), and state panel data

States compared to data-driven choice of controls (factor model)

States compared to data-driven choice of controls (synthetic controls, estimated simultaneously with employment effect) 
Table 4 Key early, recent, and summary estimates of minimum wage effects on unskilled employment (Continued)

Baskaya and Rubinstein: Using

federal minimum wage effects to

identify the impact of minimum

wages on employment and

earnings across U.S. states,

unpublished

Clemens and Wither (2014)

Appx. -0.67 , for those directly affected by minimum wage increase

Thompson (2009)

-0.3 (for teen employment share)

wage on youth labor markets,

forthcoming

Meer and West: Effects of the

minimum wage on employment

dynamics, forthcoming
States, using federally induced variation as instrumental variable

Targeted/affected workers versus other low-wage workers in states affected by federal increases

Low-wage counties vs. higher-wage counties in states

Comparisons within BEA Economic Areas (EA) that cross state lines, with controls for EA-specific shocks

State panel data, long differences with lagged effects

Notes: The table reports my best attempts to identify the authors' preferred estimates reported in the papers 
Second, the size of the average wage increase associated with a higher minimum wage-which is what will influence workers' earnings-will be smaller than the minimum wage increase itself. Letting $\Delta W^{\mathrm{A}}$ denote the average wage change of those workers whose wages are directly affected by the change in the minimum wage and $\Delta M W$ the legislated increased, and using the equation above as well, the demand elasticity for affected workers can be written as

$$
e^{A}=\left(e / p^{A}\right) \cdot\left(\Delta M W / \Delta W^{A}\right),
$$

where $\left(\Delta M W / \Delta W^{\mathrm{A}}\right)>1$. Thus, both factors blow up $e^{\mathrm{A}}$ to a larger negative number. Neumark and Wascher (2008) show, using data from the 1996-1997 minimum wage increases, that it is not implausible to assume that an overall teen elasticity of $e=-0.1$ translates into $e^{\mathrm{A}}=-0.9$, or an elasticity $e=-0.2$ into $e^{\mathrm{A}}=-1.8$, suggesting that the relevant elasticity could well be in the range in which an increase in the minimum wage leads to a reduction in the average earnings of affected low-wage workers.

Moreover, once we turn to family income, the problem is that the policy targets lowwage workers, not low-income families, and hence, the benefits are poorly targeted, for three reasons. First, over half (57 \%) of poor families with heads of household aged 18 to 64 have no workers (calculations based on 2014 CPS data). Second, some workers are poor not because of low wages but because of low hours; for example, in the same data, $46 \%$ of poor workers have hourly wages above $\$ 10.10$ and $36 \%$ have hourly wages above $\$ 12$ (two recently-proposed federal minimum wage levels). And third, due in part to the large share of teenagers in the minimum wage workforce, many lowwage workers are not in poor families (Lundstrom: When is a good time to raise the minimum wage? Contemporary Economic Policy, forthcoming).

A simple calculation demonstrates the potential problem. Suppose we simply increase wages to the new mandated level and assume no employment or hours changes. For the case of the proposed federal increase to $\$ 10.10$, based on CPS data from 2010 to 2014, $18 \%$ of the total increase in incomes would go to poor families (Lundstrom: When is a good time to raise the minimum wage? Contemporary Economic Policy, forthcoming). The distributional effects of course look better at a higher threshold for "low income", with $49 \%$ of the benefits going to families that have incomes below twice the poverty line. However, $32 \%$ would go to families with incomes at least three times the poverty line, which, for a family of four, is nearly equal to median family income in the USA. Moreover, the problem is made worse, not better, by going to a higher minimum wage, because the higher-wage workers who are affected by a higher minimum wage are less likely to be poor. For example, with a $\$ 12$ minimum wage, only $15 \%$ of the benefits go to poor families and $35 \%$ go to families with incomes at least three times the poverty line, and with a $\$ 15$ minimum wage, the corresponding figures are 12 and $38 \%$.

There are far fewer causal estimates of how minimum wages affect poverty, compared to studies of employment effects. Moreover, as emphasized by Neumark and Wascher (2008, p. 190), the answer is likely to depend on the policy environment and the distribution of income and wages. As an example, research on city-level living wages-which set higher-wage floors than minimum wages and affect different workers-finds mildly positive distributional effects. 
However, most of the research on minimum wages and poverty finds no statistical evidence of net reductions in poverty (Neumark and Wascher, 2008). ${ }^{40}$ In contrast, Dube (Minimum wages and the distribution of family incomes, Unpublished) argues that minimum wages reduce poverty. He reports that methods similar to those in Allegretto et al. (2011) - using geographically-proximate state controls-lead to evidence of strong poverty reductions from a higher minimum wage, ${ }^{41}$ and he argues that the range of estimates in the existing research is consistent with his results. There are a number of reasons to question his conclusions.

First, he uses the same methods of geographically-proximate controls that drive the findings of no employment effects. If these methods mask disemployment effects, it would not be surprising that they also suggest better distributional effects. Regardless, we see again (although with fewer studies) that conclusions more supportive of using the minimum wage to increase income from work hinge on a particular identification strategy. Second, it is difficult to view the evidence from the existing literature as consistent with Dube's findings. Nearly all of the estimates reviewed in his Table 1 for large representative samples fail to find statistically significant evidence that minimum wages reduce poverty, although many are negative. ${ }^{42}$ Third, other recent work suggests that Dube's conclusions are fragile. Sabia (2014) reports that with a longer sample period (1979-2012 versus 1990-2012), the types of specifications Dube advocates fail to point to significant effects of minimum wages on poverty (or extreme poverty), although from a policy perspective we may be interested in what more recent data show. Sabia also reports that Dube's specification with spatial controls delivers weaker anti-poverty results when the sample conditions on workers, whereas we should expect stronger results-perhaps suggestive of model misspecification-although he does not show that the specification without spatial controls is free of this problem.

Nonetheless, there are some open questions about the actual effects of minimum wages on poverty. Most of the point estimates of the effects of minimum wages on poverty are in fact negative, suggesting that it may be more likely than not that the distributional effects are in the direction of reducing poverty; a lack of statistically significant evidence does not imply that there is no effect. At the same time, one cannot appeal to a set of studies that fail to find a statistically significant negative effect of minimum wages on poverty to bolster the claim that minimum wages reduce poverty, while also appealing (more selectively) to a set of estimates of the effect of minimum wages on employment that are generally negative but statistically insignificant to argue that the minimum wage does not reduce employment.

In addition, there is some evidence that the distributional consequences of minimum wages may be slightly better in recent data. First, Lundstrom (When is a good time to raise the minimum wage? Contemporary Economic Policy, forthcoming) shows that the target efficiency of the minimum wage increased slightly over the past 10-15 years, attributable in large part to declines in income among near-poor minimum wage workers. Although the increase in target efficiency is very small, and a large share of minimum wage benefits would still go to non-poor and high-income families (as noted above); Lundstrom's work highlights how adverse changes in the distribution of wages and income can improve the targeting of the minimum wage.

Second, perhaps reflective of this, evidence in Neumark and Wascher (2011) may suggest that in more recent data the distributional effects of minimum wages are more 
favorable, as Dube (Minimum wages and the distribution of family incomes, Unpublished) argues. Some specifications in that paper focused only on the estimation of minimum wage effects, in isolation from the EITC. These estimates, reproduced in the top row of Table 5, yield an elasticity of the poverty rate with respect to the minimum wage of -0.29 . This particular conclusion could be misleading, however. First, this elasticity is for a narrow age range (21-44) of family heads, chosen because of the paper's focus on the EITC. In addition, the dependent variable is whether family earnings-rather than income as defined in the CPS and used to measure poverty-is below the poverty line.

To explore these issues, I went back to the data from that paper. I first estimated a simpler specification that is closer to the standard panel data specification in most of the poverty and minimum wage studies. The estimate is similar-a statistically significant elasticity of -0.27 (row B); the result is similar including statespecific linear trends. In row $\mathrm{C}$, however, when I use a poverty indicator as the dependent variable, the estimate becomes smaller and statistically insignificant, presumably reflecting changes in other sources of income as labor earnings change-in particular, the fact that some transfers decline when the minimum wage goes up. ${ }^{43}$ In rows $\mathrm{D}$ and $\mathrm{E}$, I drop the upper limit on the age range, to get

Table 5 Minimum wages and poverty

\begin{tabular}{|c|c|c|c|c|c|c|}
\hline \multirow[b]{2}{*}{ Description of estimate } & \multirow[b]{2}{*}{ Parameter } & \multirow[b]{2}{*}{ Sample } & \multirow[b]{2}{*}{ Estimate } & \multirow[b]{2}{*}{ Elasticity } & \multicolumn{2}{|c|}{$\begin{array}{l}\text { With state linear } \\
\text { trends }\end{array}$} \\
\hline & & & & & Estimate & Elasticity \\
\hline $\begin{array}{l}\text { A. Reported by Dube, based on } \\
\text { NW (2011, Table 6a) }\end{array}$ & $\begin{array}{l}\text { Effect on } P \text { (earnings } \\
<\text { poverty) }\end{array}$ & Ages 21-44 & -0.055 & -0.29 & $\ldots$ & $\ldots$ \\
\hline $\begin{array}{l}\text { B. Recomputed from NW data } \\
\text { w/o EITC variables and dropping } \\
\text { kids-state, kids-year interactions } \\
\text { (standard panel specification) }\end{array}$ & $\begin{array}{l}\text { Effect on } P \text { (earnings } \\
<\text { poverty) }\end{array}$ & Ages 21-44 & $\begin{array}{l}-0.051 \\
(0.023)\end{array}$ & -0.27 & $\begin{array}{l}-0.055 \\
(0.025)\end{array}$ & -0.29 \\
\hline C. Same as B, but for poverty & $\begin{array}{l}\text { Effect on } P \text { (income } \\
<\text { poverty) }\end{array}$ & Ages 21-44 & $\begin{array}{l}-0.032 \\
(0.022)\end{array}$ & -0.22 & $\begin{array}{l}-0.052 \\
(0.032)\end{array}$ & -0.35 \\
\hline $\begin{array}{l}\text { D. Same as B, but without upper } \\
\text { age restriction }\end{array}$ & $\begin{array}{l}\text { Effect on } P \text { (earnings } \\
<\text { poverty) }\end{array}$ & Age $\geq 21$ & $\begin{array}{l}-0.013 \\
(0.013)\end{array}$ & -0.04 & $\begin{array}{l}-0.018 \\
(0.024)\end{array}$ & -0.06 \\
\hline $\begin{array}{l}\text { E. Same as } C \text {, but without upper } \\
\text { age restriction }\end{array}$ & $\begin{array}{l}\text { Effect on } P \text { (income } \\
<\text { poverty) }\end{array}$ & Age $\geq 21$ & $\begin{array}{l}-0.020 \\
(0.017)\end{array}$ & -0.15 & $\begin{array}{l}-0.014 \\
(0.018)\end{array}$ & -0.11 \\
\hline \multicolumn{7}{|l|}{ Subgroups } \\
\hline F. With kids & $\begin{array}{l}\text { Effect on } P \text { (income } \\
<\text { poverty) }\end{array}$ & Age $\geq 21$ & $\begin{array}{l}-0.024 \\
(0.018)\end{array}$ & -0.18 & $\begin{array}{l}-0.029 \\
(0.031)\end{array}$ & -0.21 \\
\hline G. HS education or less & $\begin{array}{l}\text { Effect on } P \text { (income } \\
<\text { poverty) }\end{array}$ & Age $\geq 21$ & $\begin{array}{l}-0.031 \\
(0.028)\end{array}$ & -0.19 & $\begin{array}{l}-0.001 \\
(0.022)\end{array}$ & -0.01 \\
\hline H. Black or Hispanic & $\begin{array}{l}\text { Effect on } P \text { (income } \\
<\text { poverty) }\end{array}$ & Age $\geq 21$ & $\begin{array}{l}-0.035 \\
(0.029)\end{array}$ & -0.15 & $\begin{array}{l}-0.026 \\
(0.035)\end{array}$ & -0.12 \\
\hline I. Single females with kids & $\begin{array}{l}\text { Effect on } P \text { (income } \\
<\text { poverty) }\end{array}$ & Age $\geq 21$ & $\begin{array}{l}-0.108 \\
(0.040)\end{array}$ & -0.30 & $\begin{array}{l}-0.048 \\
(0.081)\end{array}$ & -0.14 \\
\hline $\begin{array}{l}\text { J. Single females with HS } \\
\text { education or less }\end{array}$ & $\begin{array}{l}\text { Effect on } P \text { (income } \\
<\text { poverty) }\end{array}$ & Age $\geq 21$ & $\begin{array}{l}-0.033 \\
(0.039)\end{array}$ & -0.12 & $\begin{array}{l}-0.008 \\
(0.041)\end{array}$ & -0.03 \\
\hline K. Single females, black or Hispanic & $\begin{array}{l}\text { Effect on } P \text { (income } \\
<\text { poverty) }\end{array}$ & Age $\geq 21$ & $\begin{array}{l}-0.026 \\
(0.051)\end{array}$ & -0.07 & $\begin{array}{l}-0.093 \\
(0.065)\end{array}$ & -0.26 \\
\hline
\end{tabular}

Notes: All estimates are weighted, and standard errors are clustered on states. Linear probability estimates are reported. The minimum wage (MW) variable is the average of the log of the contemporaneous and lagged minimum wage. In the log earnings specification, $\$ 1$ is substituted for zero earnings prior to taking logs. The estimates are robust to including state-specific linear trends. The sample is restricted to heads of families, primary individuals, or unrelated individuals. Estimates use same data and similar specification to Neumark and Wascher (2011) 
estimates more informative about the effect of the minimum wage on the poverty rate writ large. In this case, none of the estimates is statistically significant and the elasticities are smaller.

I next turn to estimates of the distributional effects for subgroups that are more disadvantaged and where the impact of the minimum wage could differ. I report results for families with kids, where the head has at most a high-school education, or where the head is black or Hispanic, families headed by single females with kids, and families headed by single females with at most a high-school education, or who are black or Hispanic. There is only a significant effect on reducing poverty in one case-for single women with kids-but this is not robust to including state-specific linear trends. Nonetheless, all of the estimates in Table 5 are negative.

These findings should not be viewed as decisive, but suggestive. ${ }^{44}$ It is perhaps surprising that few empirical analyses have zoomed in on these kinds of subgroups. DeFina (2008) studied female-headed households with kids and found negative and significant poverty reduction effects, and Sabia $(2008,2014)$ found negative but not significant poverty reduction effects for this group. A natural question is whether poverty goes up for other groups when the minimum wage increases, which could help explain why aggregate effects of minimum wages on poverty are close to zero, with minimum wages helping to reduce poverty among some subgroups with which we might be particularly concerned, even if there is no evidence of an overall beneficial effect.

This kind of conclusion is echoed in more recent evidence on distributional effects of minimum wages finding that a more generous EITC can improve the distributional effects of a higher minimum wage (Neumark and Wascher, 2011), viewed alongside the increased generosity of state EITCs in the 2000s. The basic mechanism the study conjectures is as follows. First, assume that there is heterogeneity in reservation wages among individuals who would earn wages near the minimum if they worked. In that case, either a minimum wage or an EITC can induce some individuals to enter the labor market, perhaps (especially in the case of the minimum wage) displacing others of lower productivity. ${ }^{45}$ However, there may be other individuals with higher reservation wages who enter the labor market only when there is both a high minimum wage and a more generous EITC. If these individuals are the ones to whom we would like to try to redistribute income-for example, if single mothers with children have particularly high reservation wages among roughly comparably skilled workers-then combining the EITC with a higher minimum wage may enhance the beneficial distributional effects of the EITC (and vice versa).

The results in Neumark and Wascher (2011) indicate that a combination of a higher state minimum wage and a more generous state EITC leads to higher employment and positive distributional effects for single women with children. To be clear, this research does not change the conclusion that minimum wages destroy jobs, and indeed the same combination of policies leads to more adverse employment effects than either policy in isolation for specific groups-like teenagers and less-skilled minority men-that are not eligible for the EITC, who are hit by both the higher minimum wage and increased employment by EITC recipients. But the distributional effects may still be viewed as favorable. 


\section{Conclusions}

Overall, the evidence indicates that policymakers are not powerless to boost employment or increase income from work-in either the context of countercyclical efforts following a severe downturn or the longer term. Specific types of hiring credits that states adopted in the Great Recession period-in particular, credits targeting the unemployed, and with recapture provisions-succeeded in boosting employment, although many other types of credits did not spur job growth. In addition, "deep" hiring credits in the form of generous wage subsidies often amounting to $100 \%$ were effective at motivating employers to hire disadvantaged workers after the Great Recession, with some persistence of higher employment and earnings beyond the subsidy period. Perhaps consistent with earlier research suggesting that narrowly targeted hiring credits are ineffective, these wage subsidies did not focus on the severely disadvantaged, and some subsidies targeted the long-term unemployed. This evidence on hiring credits suggests that we might consider enacting legislation that triggers hiring credits when recessions hit, as we do with UI extensions and other automatic stabilizers.

There is ample evidence that the EITC encourages increased employment, ${ }^{46}$ although it is likely not effective solely as a job creation strategy, especially during a recession and recovery. More generally, the EITC is effective at providing higher income than low-skilled workers earn on their own and does a good job of targeting poor and lowincome families with children, although it also lowers wages for some workers who are not eligible for the EITC.

The minimum wage has received the most attention of late in efforts to counter rising inequality, with many state minimum wage increases and a number of US cities implementing or considering minimum wages as high as $\$ 15$ an hour. The claim that minimum wages can be increased to more moderate levels or to levels like these without entailing job loss is not supported by most of the research evidence. However, that only establishes that there is a trade-off with potential gains from a higher minimum. Existing research does not make a strong case that a higher minimum wage would reduce poverty or help low-income families generally. But many estimates-even if not statistically significant-are in this direction, and some new evidence presented in this paper suggests that families with kids headed by low-skill women may particularly benefit, as they also do from a combination of a higher EITC and minimum wage.

Regardless, I have particularly serious concerns about the potential labor market consequences for low-skilled workers of much higher minimum wages. A $\$ 15$ per hour minimum wage corresponds to full-time, annual earnings of around $\$ 30,000$, and it seems to me that regardless of one's view of the overall evidence on minimum wages and employment, we cannot dismiss the potential adverse consequences of such high wage floors for very low-skilled workers-a group that includes a disproportionate share of minorities.

Finally, it is important to focus not just on the short-term but on the longerterm effects of these policies. Some recent research on minimum wages suggests that the employment costs grow over time. And the implications of the alternative policies for longer-term earnings growth at the individual level, via effects on human capital accumulation, have barely been explored. It seems plausible that policies that assist rather than interfering with young, unskilled workers gaining a 
foothold in the labor market are more likely to have better long-run effects that help workers become economically self-sufficient. This would argue for relying mostly on the EITC to increase incomes from work and using well-designed wage subsidies or hiring credits (as well as the EITC) to help workers obtain or regain job market opportunities.

\section{Endnotes}

${ }^{1}$ For useful statistics on the depth of the Great Recession and the speed of recovery, in comparison to past recessions, see http://www.minneapolisfed.org/publications_papers/studies/recession_perspective/, viewed January 19, 2014.

${ }^{2}$ The paper does not cover employment and training programs, such as the Workforce Investment Act (WIA), in part because some parameters had to be drawn around the policies considered and also because such policies fall more under indirect attempts to improve employment and earnings through increases in human capital, rather than direct policies to incentivize job creation or raise incomes. For a recent review of evidence on these programs and somewhat positive evaluation of the WIA, see Heinrich et al. (2013).

${ }^{3}$ See, e.g., http://www.bls.gov/news.release/empsit.t12.htm, viewed May 15, 2014.

${ }^{4}$ Despite being non-categorical, the NJTC created stronger incentives to hire lowwage workers by applying only to the first $\$ 4200$ of wages per employee.

${ }^{5}$ There is virtually no empirical work on state hiring credits. A recent, preliminary paper (Chirinko and Wilson, 2010) estimates the effects of state hiring credits, finding some modest evidence of positive effects. The Neumark and Grijalva paper differs in numerous ways, including its focus on the effects of hiring credits enacted during and after the Great Recession and using a much more comprehensive database on state hiring credit programs that captures far more credits (nearly 150 from 1969 to 2012). Bartik and Erickcek (2010) evaluated the MEGA Tax Credit Program in Michigan, which is quite different from other hiring credits in using discretionary grants. Their evaluation is quite different from the research described below, using simulations from a regional economic model. And there are some evaluations of small-scale moretargeted hiring credit (or "voucher") experiments (e.g., Burtless, 1985).

${ }^{6}$ One exception is that Kansas's Enterprise Zone Job Creation Tax Credit is included in the database, because the incentives apply statewide.

${ }^{7}$ Data on jobs and the counterfactual business cycle measure come from the Quarterly Census of Employment and Wages (QCEW).

${ }^{8}$ The HIRE Act was enacted in 2010. However, it is hard to estimate its effects. State hiring credits provide credits against state taxes, whereas the HIRE Act provided credits against federal taxes, so that the change in hiring incentives from the HIRE Act is essentially the same in all states regardless of their own credits.

${ }^{9}$ As discussed in Neumark and Grijalva, state reports indicate that these recapture provisions are actually used by states to recover credits when job creation (or other) goals are not met. For example, a list of websites providing information on penalties for noncompliance is available in Appendix 5 of Good Jobs First (2012).

${ }^{10}$ Note that the effect of ARRA spending is positive (although not significant) at long lags. This is consistent with Wilson's (2012) finding that long first-difference estimates of the effects of ARRA spending on job growth were positive, although he estimates a much different specification-including some IV estimates-and finds large positive effects that exceed substantially other estimates of job creation by the ARRA (see Neumark, 2013). 
${ }^{11}$ In principle, anticipated hiring credits (between enactment and implementation) can reduce hiring before the credit takes place, so that firms can capture the credit after it is implemented. In this case, a short-term analysis finding an employment increase in the period when a credit was enacted could reflect shifting of employment from the previous period to the current period, without any implication that on net more jobs were created. However, Table 1 reports cumulative effects out to 12 months, which grow over time for the two kinds of credits I emphasize as having positive effects-credits with recapture provisions and credits targeting the unemployed. While it is possible that some structure of adjustment costs could in principle imply that all of this response-including the growth in the effect-is the optimal adjustment to a lowering of employment prior to the credit being adopted, this seems fairly unlikely, although it cannot be decisively ruled out. As additional suggestive evidence that we are seeing a real effect, Neumark and Grijalva (2013) show that there is no relationship between lagged employment growth and the enactment of credits. That analysis was intended to rule out credits being adopted in response to prior changes in employment growth, but the empirical implications of employment being initially cut in response to credits due to take effect in the future would be the same.

${ }^{12}$ Neumark and Grijalva (2013) report on numerous additional analyses-including the addition of state-specific linear trends-that establish that these findings are quite robust and likely not reflective of endogenous adoption of hiring credits. Nonetheless, research designs that avoid this problem can be useful. As a recent example, Boockmann et al. (2012) estimate the effect of a hiring subsidy in Germany, targeted on older workers, on exits from unemployment. They use narrow age differences for eligibility to identify the effect of the subsidy.

${ }^{13}$ Cahuc et al. (2014) find that the enactment of a national hiring credit in France at the onset of the Great Recession, which targeted low-wage workers at small firms in the context of a high minimum wage, had a substantial effect on employment without inducing much churning (although it still entailed large windfalls).

${ }^{14}$ States could be reimbursed for increased welfare-related spending in one of three areas, up to $80 \%$ of a cap for each state; one of the areas of spending was subsidized jobs. Lower-Basch (2011) reports that spending on wage subsidy programs under the TANF Emergency Fund totaled $\$ 1.32$ billion. There was some additional funding (an extra $\$ 1$ billion under ARRA) via Community Services Block Grants that could be used for these programs, with relaxed criteria for the eligible population (up to $200 \%$ of the poverty line from 100 or $125 \%$ ).

${ }^{15}$ Survey evidence indicates that employers were more likely to report the reason for participation as trying out an employee before fully committing, in two sites where subsidized workers were on the payroll of a third party, compared to two other sites covered (48 and $56 \%$ versus 36 and $40 \%$ ); see Roder and Elliott (2013).

${ }^{16}$ Indeed, my view is that the main point Lower-Basch makes in her generally positive evaluation of the job subsidy programs under the TANF Emergency Fund is demonstrating that such programs could be brought to a large scale quickly, rather than that there is decisive evidence of strong job creation effects. Job creation should also imply reduced UI expenses. The only evidence I have found is a discussion of the Texas Back to Work program in Warland et al. (n.d.), noting that the Texas Workforce Commission reported high (63\%) continuation rates of 
employment after subsidies ended and net savings from reduced UI compared to those eligible for the credit who were not placed. However, the authors are cautionary about the validity of this comparison, because of potential differences between those who were and were not placed.

${ }^{17}$ They also report consistent evidence from an employer survey, in which $76 \%$ indicated that they retained at least one subsidized worker after the subsidy period ended, and overall that $37 \%$ of workers were retained.

${ }^{18}$ Florida (and one other site Roder and Elliott cover) did not provide pre-placement services, although participants could already access services available at One-Stop Career Centers.

${ }^{19}$ Such incentives were used in the Washington State Community Jobs Program (Warland et al., n.d.). I have not found other discussion of use of such incentives in the many programs set up under the TANF Emergency Fund.

${ }^{20}$ See, e.g., http://articles.latimes.com/2014/jan/31/business/la-fi-obama-jobs-20140201, viewed May 15, 2014.

${ }^{21}$ See https://www.congress.gov/bill/113th-congress/house-bill/2821, viewed January 19, 2016

${ }^{22}$ Most EITC recipients chose to take their payment as a lump sum at the end of the year rather than in each paycheck. (The latter was an option that ended after 2010.) This choice to take the lump sum may have been in part to avoid stigma effects.

${ }^{23}$ For recent evidence on this characterization of the Great Recession, see Rothstein (2014). For a different interpretation, see Mulligan (2012).

${ }^{24}$ See http://www.whitehouse.gov/sites/default/files/docs/eitc_report.pdf, viewed May 16, 2014.

${ }^{25}$ State EITCs were implemented in additional states subsequently.

${ }^{26}$ For similar evidence for the UK, see Leigh (2007), and for related US evidence, see Neumark and Wascher (2001).

${ }^{27}$ Bitler et al. (2014) study how income support policies operate during recessions, in contrast to this paper's focus on policies to increase jobs and income from work in the aftermath of the Great Recession. They show that the EITC does not always smooth negative income shocks during recessions. It does this for married couples-for whom reductions in combined incomes move them to lower incomes along the phaseout range of the EITC, or make them eligible-but not for single parents-for whom job loss ends eligibility or lower earnings on the phase-in range imply smaller payments. This echoes a more general limitation of the EITC or other in-work policies-that it provides nothing for those who cannot work or cannot find work. Thus, the EITC is not a complete substitute for other forms of income support for those with no or very low earnings.

${ }^{28} \mathrm{~A}$ very interesting evaluation of an experimental EITC program in New York City-Paycheck Plus-is currently underway, with results expected in 2017/2018 (see http://www.mdrc.org/publication/paycheck-plus-making-work-pay-low-incomesingle-adults, viewed October 9, 2014).

${ }^{29}$ This evidence comes from shocks across regions in import competition from Chinese manufacturing. Clearly, this source of variation is not the same as increasing employment subsidies to childless men; but it does provide plausibly causal evidence linking higher employment among men to marriage and family structure. 
${ }^{30}$ This is speculative but is in some sense the flip side of the results in Neumark and Nizalova (2007) suggesting that minimum wages may have long-term adverse effects on wages and employment, stemming in part from lost work experience. Recent evidence in Dahl et al. (2009) suggests that single women induced to enter the labor market because of the EITC had higher subsequent earnings growth, possibly via increased human capital accumulation stemming from the positive employment effects of the EITC, although this study is based on considerably earlier data only from federal expansions of the EITC in the early 1990s.

${ }^{31}$ Mulheirn and Pisani (Estimating the labor supply effect of the working tax credit for childless households in the UK, Unpublished) report a positive employment effect from the introduction of an earned income tax credit for childless adults in the UK.

${ }^{32}$ See http://www.whitehouse.gov/sites/default/files/uploads/sotu_minimum_wage.pdf, viewed May 9, 2014.

${ }^{33}$ See http://www.nytimes.com/2014/01/05/business/help-the-working-poor-but-sharethe-burden.html?src=recg\&_r=0, viewed May 19, 2014.

${ }^{34}$ See, e.g., http://www.bloomberg.com/news/2013-11-13/how-mcdonald-s-and-walmart-became-welfare-queens.html, viewed May 19, 2014.

${ }^{35}$ See also Leigh (2010). Rothstein's analysis also suggests that a negative income tax (NIT), because it reduces labor supply via income effects, would deliver larger gains in income per dollar spent. And of course, an NIT offers the important advantage of providing resources to those who cannot work, for whom we currently provide benefits in many other ways that may be far more expensive administratively and in some cases imply higher implicit marginal tax rates than an NIT. This paper, however, focuses on policies that raise incomes from work. How to supply basic needs to the population including those who do not work is a different problem with its own set of complications (see Moffitt, 2003).

${ }^{36}$ The figure in the original Doucouliagos and Stanley paper restricts the range of the $x$-axis much more severely. We are not sure where Schmitt's version of the figure comes from; we suspect it is from an unpublished version of the paper.

${ }^{37}$ Gittings and Schmutte (Getting handcuffs on an octopus: minimum wages, employment, and turnover, Unpublished) report similar results on employment effects, using approaches similar to those in Allegretto et al. Addison et al. (2013) also use similar methods to estimate effects for teens and restaurant workers from the three-step federal minimum wage increase over 2007-2009. They find limited overall evidence of disemployment effects; the elasticities vary from positive to negative but tend to be more negative but also statistically insignificant. However, for teens there is stronger evidence of disemployment effects when the recession hit, with an estimated significant elasticity of -0.34 at the average unemployment rate in 2008-2009.

${ }^{38}$ Neumark et al. (2014b) also discuss another specification issue raised in the Allegretto et al. and Dube et al. studies concerning detrending the data. In my view, however, the more cogent challenge in the earlier studies comes from the issue of the choice of control states, which is why I emphasize that issue here.

${ }^{39}$ This estimate cannot be compared directly to other elasticity estimates, because there is no population count in the data source used.

${ }^{40}$ Another issue is who bears the costs. A recent simulation study (MaCurdy, 2015) calculates the price effects of a minimum wage increase and characterizes its effects as akin to a sales or value-added tax that is even more regressive than a standard sales tax. 
${ }^{41}$ In the recent $\mathrm{CBO}$ study of the effects of a higher minimum wage, the approximate elasticity of the number of poor people with respect to the minimum wage is -0.05 (Congressional Budget Office, 2014; p. 11). Dube's estimated elasticity of the poverty rate with respect to the minimum wage in his preferred specifications is -0.24 to -0.36 .

${ }^{42}$ Some of the estimates in Addison and Blackburn (1999) point to significant reductions in poverty, but these are for very narrow subsets of the population and hence largely irrelevant to the policy question. One other exception, to which I return below, is DeFina (2008), who studies female-headed households with children.

${ }^{43}$ For related evidence on this in the context of a proposed living wage increase, see Neumark et al. (2013).

${ }^{44}$ There is also nearly an infinite number of ways to define subgroups, and some (like using an age range of 16-64) give results that are sometimes statistically significant, although not for both the models with and without state-specific linear trends. Dube (Minimum wages and the distribution of family incomes, Unpublished) only reports original results for those under age 65 , which as this note indicates is the group for which there is more evidence (although non-robust) of beneficial distributional effects. It is not immediately obvious why we would not be interested in those aged 65 and over, who can be either directly or indirectly (through other workers in their families) affected by minimum wages.

${ }^{45}$ The conventional theory does not imply that employment of any particular subgroup will decrease in response to a higher minimum wage; it only predicts that overall labor demand for less-skilled workers will fall. In particular, individuals for whom the market wage was previously below the reservation wage could be drawn into the labor force after a minimum wage increase.

${ }^{46}$ The evidence that the EITC increases employment on the extensive margin seems unambiguous. More generally, evidence cited earlier suggests net positive labor supply effects in the aggregate, although they are not large.

Competing interests

The IZA Journal of Labor Policy is committed to the IZA Guiding Principles of Research Integrity. The author declares that he has observed these principles.

Acknowledgements

I would like to thank the anonymous referee and the editor for the useful comments.

Responsible editor: Juan Jimeno

Author details

${ }^{1}$ University of California, Irvine, Irvine, CA, USA. ${ }^{2}$ NBER, Cambridge, MA, USA. ${ }^{3}$ IZA, Bonn, Germany.

Received: 23 July 2015 Accepted: 7 January 2016

H.

References

Addison JT, Blackburn ML (1999) Minimum wages and poverty. Industrial and Labor Relations Review 52:393-409

Addison JT, Blackburn ML, Cotti CD (2013) Minimum wage increases in a recessionary environment. Labour Economics 23:30-39

Allegretto SA, Dube A, Reich M (2011) Do minimum wages really reduce teen employment? Accounting for heterogeneity and selectivity in state panel data. Industrial Relations 50:205-240

Allegretto S, Dube A, Reich M, Zipperer B (2015) Credible research designs for minimum wage studies: A response to Neumark, Salas and Wascher. IRLE Working Paper No.116-15

Ashenfelter O, Harmon C, Oosterbeek H (1999) A review of estimates of the schooling/earnings relationship, with tests for publication bias. Labour Economics 6:453-470

Autor D (2011) The polarization of job opportunities in the U.S. labor market: Implications for employment and earnings. Community Investments 23(2):11-41

Bartik TJ (1991) Who benefits from state and local economic development policies? Upjohn Institute, Kalamazoo, MI 
Bartik TJ, Erickcek GA (2010) The employment and fiscal effects of Michigan's MEGA tax credit program. Upjohn Institute Working Paper No. 10-164

Belman D, Wolfson PJ (2014) What does the minimum wage do? Upjohn Institute, Kalamazoo, MI

Bengali L, Daly M, Valletta R (2013) Will labor force participation bounce back? Economic Letter, Federal Reserve Bank of San Francisco, San Francisco, California, May 13

Berlin GL (2007) Rewarding the work of individuals: A counterintuitive approach to reducing poverty and strengthening families. Future of Children 17:17-42

Bitler M, Hoynes H, Kuka E (2014) Do in-work tax credits serve as a safety net? NBER Working Paper No. 19785

Borjas G (2010) Labor economics, 5th edn. McGraw-Hill, New York

Boockmann B, Zwick T, Ammermüller A, Maier M (2012) Do hiring subsidies reduce unemployment among older workers? Evidence from natural experiments. Journal of the European Economic Association 10:734-764

Brown C, Gilroy C, Kohen A (1982) The effect of the minimum wage on employment and unemployment. Journal of Economic Literature 20:487-528

Burtless G (1985) Are targeted wage subsidies harmful? Evidence from a wage voucher experiment. Industrial and Labor Relations Review 39:105-114

Cahuc P, Carcillo S, Le Barbanchon T (2014) Do hiring credits work in recessions? Evidence from France. IZA Discussion Paper No. 8330

Carrasso A, Holzer HJ, Maag E, Steuerle EC (2008) The next stage: Encouraging work and family formation among low-income men. Urban-Brookings Tax Policy Center Discussion Paper No. 28

Chirinko RS, Wilson DJ (2010) Job creation tax credits and job growth: Whether, when, and where? Federal Reserve Bank of San Francisco Working Paper 2010-25

Clemens J, Wither M (2014) The minimum wage and the Great Recession: Evidence of effects on the employment and income trajectories of low-skilled workers. NBER Working Paper No. 20724

Congressional Budget Office (2014) The effects of a minimum-wage increase on employment and family income

Dahl M, DeLeire T, Schwabish J (2009) Stepping stone or dead end? The effect of the EITC on earnings growth. National Tax Journal 62:329-346

DeFina RH (2008) The impact of state minimum wages on child poverty in female-headed households. Journal of Poverty 12:155-174

Dickert S, Houser S, Scholz JK (1995) The earned income tax credit and transfer programs: A study of labor market and program participation. Tax Policy and the Economy 9:1-50

Dickert-Conlin S, Holtz-Eakin D (2000) Employee-based versus employer-based subsidies to low-wage workers: A public finance perspective. In: Card DE, Blank RM (eds) Finding jobs: Work and welfare reform. Russell Sage Foundation, New York, pp 373-419

Doucouliagos H, Stanley TD (2009) Publication selection bias in minimum-wage research? A meta-regression analysis. British Journal of Industrial Relations 4:406-428

Dube A (2011) Review of Minimum Wages by David Neumark and William L. Wascher. Journal of Economic Literature 49:762-766

Dube A, William Lester T, Reich M (2010) Minimum wage effects across state borders: Estimates using contiguous counties. Review of Economics and Statistics 92:945-964

Ehrenberg RG, Smith RS (2009) Modern labor economics, tenthth edn. Pearson Education, Inc., Boston, MA

Eissa N, Hoynes H (2011) Redistribution and tax expenditures: The earned income tax credit. National Tax Journal 64: 689-730

Eissa N, Liebman JB (1996) Labor supply response to the earned income tax credit. Quarterly Journal of Economics 111: 605-637

Farrell M, Elkin S, Broadus J, Bloom D (2011) Subsidizing employment opportunities for low-income families: A review of state employment programs created through the TANF Emergency Fund. Office of Planning, Research and Evaluation Report 2011-38

Good Jobs First (2012) Money-back guarantees for taxpayers: Clawbacks and other enforcement safeguards in state economic development subsidy programs. Good Jobs First. Washington, DC

Freeman RB (1996) The minimum wage as a redistributive tool. Economic Journal 106:639-649

Gitterman DP, Gorham LS, Dorrance JL (2008) Expanding the EITC for single workers and couples without children: Tax relief for low-wage workers. Georgetown Journal of Poverty Law \& Policy 15:245-284

Hamersma S (2003) The work opportunity and welfare-to-work tax credits: Participation rates among eligible workers. National Tax Journal 56:725-738

Heaton P (2012) The effects of hiring tax credits on employment of disabled veterans. RAND National Defense Research Institute Occasional Paper, Santa Monica, CA

Heinrich Carolyn J, Mueser PR, Troske KR et al (2013) Do public employment and training programs work? IZA Journal of Labor Economics 2:6, on-line

Hotz VJ, Scholz JK (2003) The Earned Income Tax Credit. In: Moffitt RA (ed) Means-tested transfer programs in the United States. Russell Sage Foundation, New York, pp 141-198

Hunt M (1997) How science takes stock. Russell Sage Foundation, New York

Johnson KP, Kor JR (2004) 2004 redefinition of BEA Economic Areas. Survey of Current Business, November, pp. 68-75

Katz LF (1998) Wage subsidies for the disadvantaged. In: Freeman RB, Gottschalk P (eds) Generating jobs: How to increase demand for less-skilled workers. Russell Sage Foundation, New York, NY, pp 21-53

Keane M, Moffitt R (1998) A structural model of multiple welfare program participation and labor supply. International Economic Review 39:553-589

Kroft K, Lange F, Notowidigdo MJ (2013) Duration dependence and labor market conditions: Evidence form a field experiment. Quarterly Journal of Economics 128:1123-1167 
Kroft K, Lange F, Notowidigdo MJ, Katz LJ (2014) Long-term unemployment and the Great Recession: The role of composition, duration dependence, and non-participation. NBER Working Paper No. 20273, Cambridge, MA, [Internet], viewed July 9, 2014

Krugman P (2015) Liberals and wages. New York Times, July 17, http://www.nytimes.com/2015/07/17/opinion/paulkrugman-liberals-and-wages.html?_r=1, viewed July 21, 2015

Leigh A (2007) Earned income tax credits and labor supply: New evidence from a British natural experiment. National Tax Journal 60:205-224

Leigh A (2010) Who benefits from the earned income tax credit? Incidence among recipients, coworkers, and firms. BE Journal of Economic Analysis \& Policy 10:1, on-line

Liebman JB (1998) The impact of the earned income tax credit on incentives and the income distribution. In: Poterba J (ed) Tax policy and the economy, volume 12. MIT Press, Cambridge, MA, pp 83-120

Lower-Basch E (2011) Rethinking work opportunity: From tax credits to subsidized placements. CLASP, http://www. clasp.org/resources-and-publications/files/Big-Ideas-for-Job-Creation-Rethinking-Work-Opportunity.pdf, viewed May 15,2014

MaCurdy T (2015) How effective is the minimum wage at supporting the poor? Journal of Political Economy 123:497-545

Meyer BD, Rosenbaum DT (2001) Welfare, the earned income tax credit, and the labor supply of single mothers. Quarterly Journal of Economics 116:1063-1114

Moffitt RA (2003) The negative income tax and the evolution of U.S. welfare policy. Journal of Economic Perspectives 17:119-140

Mulligan CB (2012) The redistribution recession: How labor market distortions contracted the economy. Oxford University Press, New York

Neumark D (2013) Spurring job creation in response to severe recessions: Reconsidering hiring credits. Journal of Policy Analysis \& Management 32:142-171

Neumark D, Grijalva D (2013). The employment effects of state hiring credits during and after the Great Recession. NBER Working Paper No. 18928

Neumark D, Nizalova O (2007) Minimum wage effects in the longer run. Journal of Human Resources 42:435-452

Neumark D, Salas IJM, Wascher W (2014a). More on recent evidence on the effects of minimum wages in the United States. IZA Journal of Labor Policy, 3:24

Neumark D, Salas IJM, Wascher W (2014b) Revisiting the minimum wage-employment debate: Throwing out the baby with the bathwater? Industrial and Labor Relations Review 67:608-648

Neumark D, Thompson M, Brindisi F, Koyle L, Reck C (2013) Simulating the economic impacts of living wage mandates using new public and administrative data: Evidence for New York City. Economic Development Quarterly 27:271-283

Neumark D, Thompson M, Koyle L (2012) The effects of living wage laws on low-wage workers and low-income families: What do we know now? IZA Journal of Labor Policy, 1:11

Neumark D, Wascher W (2001) Using the EITC to help poor families: New evidence and a comparison with the minimum wage. National Tax Journal 54:281-317

Neumark D, Wascher W (2002) State-level estimates of minimum wage effects: New evidence and interpretations from disequilibrium models. Journal of Human resources 37:35-62

Neumark D, Wascher W (2008) Minimum wages. MIT Press, Cambridge, MA

Neumark D, Wascher W (2011) Does a higher minimum wage enhance the effectiveness of the earned income tax credit? Industrial and Labor Relations Review 64:712-746

Neumark D, William W (2007) Minimum wages and employment. Foundations and Trends in Microeconomics 3:1-186

LaDonna P, Schott L, Lower-Basch E (2011) Creating subsidized employment opportunities for low-income parents. Center on Budget and Policy Priorities and CLASP, http://www.cbpp.org/files/2-16-11tanf.pdf, viewed May 15, 2014

National Employment Law Project (2012) The low-wage recovery and growing inequality. Data Brief, http://www.nelp. org/page/-/Job_Creation/LowWageRecovery2012.pdf?nocdn=1, viewed January 19, 2014

Roder A, Elliott M (2013) Stimulating opportunity: An evaluation of ARRA-funded subsidized employment programs. Economic Mobility Corporation, http://economicmobilitycorp.org/uploads/stimulating-opportunity-full-report.pdf, viewed May 15, 2014

Rothstein J (2011) Is the EITC as good as an NIT? Conditional cash transfers and tax incidence. American Economic Journal: Economic Policy 2:177-208

Rothstein J (2014) The Great Recession and its aftermath: What role for structural changes? IRLE Working Paper No. $115-15$

Sabia J (2008) Minimum wages and the economic well-being of single mothers. Journal of Policy Analysis and Management 27:848-866

Sabia JJ (2014) Minimum wages: An antiquated and ineffective anti-poverty tool in Journal of Policy Analysis and Management 33:1028-1036

Schmitt J (2013) Why does the minimum wage have no discernible effect on employment? Center for Economic and Policy Research Working Paper

Scholz JK (1994) The earned income tax credit: Participation, compliance, and anti-poverty effectiveness. National Tax Journal 47:63-87

Thompson JP (2009) Using local labor market data to re-examine the employment effects of the minimum wage. Industrial and Labor Relations Review 62:343-366

Totty E (2014) The effect of minimum wages on employment: A factor model approach. Purdue University, Institute for Research in the Behavioral, Economic, and Management Sciences, Working Paper No. 1278

Warland C, Young M, Lower-Basch E. n.d. Innovative city and state funding approaches to supporting subsidized employment and transitional jobs. National Transitional Jobs Network and CLASP, http://www.clasp.org/resourcesand-publications/publication-1/Transitional-Jobs-Report_Warland-Young-Lower-Basch.pdf, viewed May 15, 2014 
Washington State Institute for Public Policy (2005) Evaluating Washington State's Community Jobs program: Two-year employment outcomes of 2002 enrollees, http://www.wsipp.wa.gov/ReportFile/918/Wsipp_Evaluating-WashingtonStates-Community-Jobs-Program-Two-Year-Employment-Outcomes-of-2002-Enrollees_Full-Report.pdf, viewed May 15,2014

Wilson DJ (2012) Fiscal spending multipliers: Evidence from the 2009 American Recovery and Reinvestment Act. American Economic Journal: Economic Policy 4:251-282

Submit your manuscript to a SpringerOpen ${ }^{\circ}$ journal and benefit from:

- Convenient online submission

- Rigorous peer review

- Immediate publication on acceptance

- Open access: articles freely available online

- High visibility within the field

- Retaining the copyright to your article

Submit your next manuscript at $>$ springeropen.com 